\title{
WTO Accession and Performance of Chinese Manufacturing Firms ${ }^{\S}$
}

\author{
By Loren Brandt, Johannes Van Biesebroeck, Luhang Wang, \\ AND YIFAN ZHANG*
}

\begin{abstract}
We examine the effects of trade liberalization in China on the evolution of markups and productivity of manufacturing firms. Although these dimensions of performance cannot be separately identified when firm output is measured by revenue, detailed price deflators make it possible to estimate the average effect of tariff reductions on both. Several novel findings emerge. First, cuts in output tariffs reduce markups, but raise productivity. Second, pro-competitive effects are most important among incumbents, while efficiency gains dominate for new entrants. Third, cuts in input tariffs raise both markups and productivity. We highlight mechanisms that explain these findings in the Chinese context. (JEL
\end{abstract} D22, D24, F12, F13, F14, L11)

"The competition arising [from WTO membership] will also promote a more rapid and more healthy development of China's national economy"

Premier Zhu Rongji (Press release, Washington, DC, April 1999)

China's manufacturing sector experienced impressive productivity growth over much of the 1990s and 2000s before the onset of the Great Recession (Brandt, Van Biesebroeck and Zhang, 2012). Expanded access to international markets and export growth are often cited as key

\footnotetext{
$\S$ Go to ... for additional materials and author disclosure statement(s).
}

* Brandt: Department of Economics, University of Toronto, 150 St. George Street, Toronto, ON M5S 3G7, Canada (e-mail: brandt@chass.utoronto.ca); Van Biesebroeck: Department of Economics, KU Leuven, Naamsestraat 69, 3000 Leuven, Belgium, and CEPR (e-mail: jo.vanbiesebroeck@kuleuven.be); Wang: Department of International Economics and Trade, Xiamen University, Economics Building, 361005 Xiamen, China and Wang Yanan Institute for Studies in Economics (e-mail: luhangwang@xmu.edu.cn); Zhang: Department of Economics, Chinese University of Hong Kong, Shatin, N.T., Hong Kong (e-mail: yifan.zhang@ cuhk.edu.hk). We thank seminar participants at Columbia, Frankfurt, Nottingham, Princeton, Yale, the World Bank, and Zurich, and several conferences for comments. Special thanks to Jan De Loecker for extensive feedback on estimation and identification problems. Brandt acknowledges funding from SSHRC. Van Biesebroeck acknowledges funding from ERC (Starting Grant No. 241127) and KU Leuven Program Financing. Wang acknowledges funding from Fujian Provincial Science Foundation (Grant No. 2015J05139). The authors declare that they have no relevant or material financial interests that relate to the research described in this paper. 
drivers of this improvement (Yu, 2014; Khandelwal, Schott and Wei, 2013). 1 Largely neglected is the impact on local firms of reforms that facilitated access to China's domestic market for the rest of the world. Chinese leaders such as Premier Zhu Rongji, constrained by domestic political economy considerations in their efforts to restructure major segments of industry, believed that reforms required as a condition for WTO accession would be an important catalyst for change. 2

A large literature examines the effects of trade liberalizing reforms on productivity, but there is little work estimating the effects of these same policies on markups. An advantage of looking at markups compared to productivity is that they can be estimated without observing firm-level prices. A complication is that, in addition to efficiency gains, they also capture effects on equilibrium prices in output and input markets. From the definition of the markup, i.e. the ratio of price to marginal cost, we can decompose trade-induced changes in output prices into changes in markups, input prices, and production efficiency. These correspond to three independent, welfare-enhancing effects of trade liberalization. First, lowering import tariffs increases competition and induces firms with market power to lower their markups (Levinsohn, 1993). This behavior raises consumer surplus at the expense of producer surplus, but also reduces allocative distortions. Second, lowering tariffs on imports of intermediate goods directly reduces marginal costs (Tybout and Westbrook, 1995). And third, marginal costs can also fall due to higher productivity or efficiency. While all three mechanisms, ceteris paribus, reduce output prices and raise welfare, the second two will increase markups unless passthrough of cost savings is perfect. The relationship between the markup and gains from trade is thus not monotonic, but depends on the mechanism at work.3

We use firm-level data that covers most of the manufacturing sector in China to investigate the role of domestic trade liberalization over a period that spans China's entry into the WTO in 2001. Our results indicate that differences in performance across industries are systematically related to variation in tariff reductions. Although productivity cannot be separately identified from the markup when one does not observe firm-level output and input prices (Garcia and Voigtländer, 2013), our interest is not in the levels, but rather in the covariance of the performance dimensions with tariffs. The productivity measure that we estimate using detailed

\footnotetext{
1 The important consequences of these changes for global welfare have been noted as well, see di Giovanni, Levchenko and Zhang (2014) and Autor, Dorn and Hanson (2013).

2 The sentiments in the quote above, made after ironing out final details about the WTO accession with President Clinton, is echoed by several researchers. For example, Branstetter and Lardy (2008) also view more competition as an essential source of pressure that forced structural reforms.

3 Moreover, while the last two mechanisms are expected to raise markups, the extent depends on the pass-through of cost savings into prices, further complicating the link from markups to welfare.
} 
industry-level price deflators to deflate nominal values contains firm-specific price deviations from the average price evolution. However, these price deviations are by construction uncorrelated with changes in industry-level tariffs if the regression applies the same weight to firms as their products receive in the construction of the industry deflator. Thus, if price deflators and tariff cuts are observed at the same level of detail, it is possible to estimate the average effect of trade liberalization separately on efficiency and markups.

We estimate the production function and recover markups as in De Loecker and Warzynski (2012), who implement the estimator proposed by Ackerberg, Caves and Frazer (2016). Consistent estimation in the absence of firm-specific price information requires that the unobservable firm heterogeneity can be represented by a single-dimensional state variable (Ackerberg et al., 2007). In this case, the control function that absorbs the effects of unobservable productivity differences controls for both endogenous input choices and the possible endogeneity of output or input prices (De Loecker et al. 2016). 'Revenue' TFP, socalled TFPR, is obtained as a residual of the production function.

Our first contribution is to separately identify the effects on firm-level markups of reducing output tariffs and tariffs applied to an industry's inputs, as Amiti and Konings (2007) originally did for productivity. We find a negative effect of input tariffs on markups, which reflects their direct effect on input prices. The effect of output tariffs, on the other hand, is positive, but only statistically significant if we use firm weights. Trade liberalization reduces markups of larger firms, but has no significant effect on the average over the entire sample. Note that this effect introduces a systematic relationship between the deviations of firm-specific prices from the industry price deflator. The gap will be decreasing in size, i.e. positive for small firms that do not adjust their markup and negative for large firms. As a result, if all firms are given equal weight, the coefficient on output tariffs in the productivity regression will be biased downwards, and the productivity-boosting effect of trade liberalization will be overestimated. The use of within-industry firm weights corrects for this.

Our second contribution is to contrast effects on markups with those on productivity in order to provide insights into the mechanisms through which trade liberalization effects materialize. Our results for China confirm that lower input tariffs lead to higher productivity, as was the case for Indonesia (Amiti and Konings, 2007) and India (Topolova and Khandelwal, 2011).4 For a Cobb-Douglas production function, the effect of an external factor on the markup can be

4 Note that the average effect on input prices is already accounted for through the effect on the input price deflator and we should interpret the effect on productivity as an efficiency effect. Separate price regressions show a remarkably strong effect of tariff reductions on domestic price deflators, even exceeding the share of imports in domestic consumption. 
decomposed into an effect on TFP and the net impact of opposing effects on output and input prices (De Loecker and Goldberg, 2014). Given that we find a larger effect of input tariffs on productivity than on markups (in absolute value), the pass-through of cost savings into lower output prices must outweigh the direct input price effect of the input tariff cut. This is only possible if the cost savings include some efficiency gains.

In contrast with the studies mentioned above, we find that cuts in output tariffs also raise productivity, indicating that more competition triggers efficiency improvements.5 Combined with the insignificant coefficient of output tariffs in the markup regression, our results imply that competition puts downward pressure on output prices and that most efficiency gains are passed on to consumers. This is consistent with the directly estimated effect of tariffs on output prices which is of a similar magnitude as the effect on productivity, but has an opposite sign. For large firms, the pro-competitive and price-reducing effect even dominates and the coefficient on markups turns positive.

Our third contribution is to obtain further insights into the mechanisms by decomposing the aggregate effect. Several of the patterns that we document are intuitive. The pro-competitive effect of output tariff cuts on markups only shows up robustly for incumbents, who are more likely to possess market power. The efficiency gains associated with input tariff cuts are much stronger for new entrants, who likely have more flexibility to adjust their production process and take advantage of the new opportunities. We find some efficiency gains for incumbents, but they are offset by a deterioration in resource allocation as the correlation between market share growth and the firm-level productivity level becomes weaker in sectors where input tariffs fall the most.

One pattern unique to China is a significant negative effect of output tariffs on TFP, even after controlling for input tariffs. Effects of trade liberalization in other countries point mostly to benefits from the availability or cheaper access to imported intermediates, but we find that their share in total input use barely increased in China.6 The productivity effects in China show up for both incumbents and new entrants. For incumbent firms, one plausible mechanism is that increased competition affects the agency problem between managers and owners. It can both strengthen incentives to make productivity-enhancing investments (Raith, 2003; Chen,

5 When Amiti and Konings (2007) include both tariff rates in their productivity regression, the input tariff coefficient is six times the size of the output tariff coefficient, and the latter is statistically insignificant when they cluster standard errors at the industry-year level. The output tariff coefficient is only significant at the 10\% level in Topolova and Khandelwal (2011) who cluster only at the firm level.

6 Lower input tariffs have a strong price-reducing effect in upstream industries, even for domestically produced intermediates, but the average effect is already controlled for through the (input) price deflators. These benefits could include higher quality of imported inputs that are not be fully reflected in prices or greater input variety that generates a production complementarity (Halpern, Koren and Szeidl, 2015). 
2014) and weaken resistance to productivity-enhancing reorganizations (Schmitz, 2005). For private firms, we show that the probability of exit increases in liberalized industries, providing direct performance incentives through a greater threat of bankruptcy. For state-owned firms that face softer budget constraints, we show that the probability of replacing the CEO after a spell of low growth increases, pointing to a deliberate change in governance practice. A separate channel we document is a higher initial productivity for entrants relative to incumbents in liberalized industries. With stronger competition, selection at entry becomes more stringent which raises the relative productivity of successful entrants, as in the model with spatial competition of Syverson (2004). This pattern is consistent with the large role that Khandelwal et al. (2013) attribute to net entry in explaining the surge in Chinese exports after the removal of textile quotas.

Our results are most closely related to the work of De Loecker et al. (2016) for India. In a similar specification as ours, they also find a strong negative relationship between markups and input tariffs, but no significant relationship between markups and output tariffs. They emphasize that cost-reducing effects of trade liberalization, either directly through input prices or indirectly through improved efficiency as we found in China, give firms a strong incentive to raise markups. Since they observe firm-level prices, they are able to construct an estimate for marginal cost. Once controlled for, they find an unambiguous pro-competitive effect of output tariff cuts on markups. Their point estimates of this effect for India is remarkably similar to the (combined) effect we estimate for China: each percentage point reduction in output tariffs lowers markups between 0.10 and 0.15 log-points.

Two other studies have looked at the impact of trade liberalization on markups, but focus on markup dispersion and its effect on resource misallocation. Edmond, Midrigan and Xu (2015) calculate gains from trade by comparing the observed equilibrium for Taiwan with a simulated autarky situation, assuming oligopolistic competition throughout. They find that the procompetitive effect in concentrated industries has a first-order effect on welfare by reducing misallocation and this effect is increasing in the cross-country correlation in sectoral productivity. Lu and $\mathrm{Yu}$ (2015) show that the dispersion in markups in China decreased following its entry in the WTO, mostly due to a relative decline at the top which is consistent with our findings.

Finally, our findings are related to several strands in the literature that aim to understand the aggregate productivity effects of trade liberalization. Decomposing aggregate changes, several influential studies highlight the important benefits due to exit of unproductive firms (Eslava et al., 2013) and the reallocation of market share away from unproductive firms (Pavcnik, 2002). 
The theoretical framework that Arkolakis et al. (2012) use to assess the gains from trade does not allow any role for within-firm productivity growth, which we estimate to be an important mechanism in China. Moreover, complementarity between trade and industrial policy has been a central issue in the study of transitions to a market economy (Murphy, Shleifer and Vishny, 1992). Our estimates provide micro-level evidence for the complementarity between trade liberalization on one hand and deregulation of firm entry or reforming loss-making state-owned firms on the other.7

The remainder of the paper is organized as follows. Section 2 discusses the relevant policy history that led to increased international competition in China. Section 3 provides a conceptual framework for the analysis and discusses estimation issues. Section 4 describes the data. Section 5 shows the impact of tariff reductions on several margins and in Section 6 we discuss corroborating evidence for several mechanisms that could explain the estimated effects. Section 7 concludes.

\section{Increased international competition}

\section{A. Policy regime}

In the late 1970s China embarked on a radical path of economic reforms. Opening the economy to the rest of the world was an integral part of these reforms from the beginning. China established four Special Economic Zones in 1980 and Economic and Technical Development Zones in fourteen coastal cities in 1984, to encourage entry of foreign direct investment (FDI) and the development of a manufacturing export sector through the importation of much-needed capital, managerial know-how, and technology. Outside of these zones it allowed the importation and licensing of new technologies and capital goods as part of a policy to modernize existing domestic enterprises. It concurrently reduced tariff and non-tariff barriers on a unilateral basis and extended direct trading rights to more firms, culminating in its entry into the World Trade Organization (WTO) at the end of 2001.

Even before its accession to WTO, China's manufacturing sector was already relatively open on several dimensions. First, as part of its policy of encouraging FDI for exporting, China exempted mostly foreign firms involved in export processing from tariffs on imported raw materials, intermediates, and capital equipment. Exemption of import duties was expanded in

7 Using cross-country regressions, Freund and Bolaky (2008) establish a similar connection between trade liberalization and deregulation of entry at the aggregate level. 
the second half of the 1990s to certain types of domestic firms. Branstetter and Lardy (2008) report that in 2000 less than 40 percent of imports were subject to tariffs. Second, beginning in the early 1990s, China started to reduce its domestic tariffs, from 43.2 percent in 1992 (unweighted average at the 8-digit HS level) to 15.3 in 2001. These measures were accompanied by a reduction in the share of imports regulated by non-tariff barriers through licenses and quotas (Branstetter and Lardy, p. 635). This process continued as part of its negotiated WTO entry, only now some tariff reductions were less voluntary.

China's renewed openness complemented reform initiatives geared towards the domestic economy. Thousands of state and collective-owned enterprises were either sold off or allowed to go bankrupt, while entry restrictions on domestic private firms were relaxed tremendously. 8 Imperceptible in the mid-1990s, employment in private firms rose to almost one-third of manufacturing employment by 2007 (Brandt et al. 2012). These wide-ranging reforms served as catalyst for economic growth that has averaged nearly 8 percent per annum in per capita terms since the start of reforms.

\section{B. Quantifying the extent of trade liberalization}

We obtained import tariff rates at the 8-digit level of the Harmonized System (HS) product classification from the World Bank's WITS dataset. We map them into China's Industrial Classification (CIC) system at the 4-digit level (424 manufacturing industries) to obtain output tariffs that we use in the firm and industry-level analysis.9 To avoid any bias in the industry average due to low trade volumes in heavily protected product lines, we use an unweighted average. Input tariffs are a weighted average of output tariffs, using as weights the industry input shares from the 2002 Input-Output (IO) table. Reflecting the higher level of aggregation of the Chinese IO table, the input tariffs are effectively at the 3-digit level. By constructing a consistent industry classification over time, accounting for important changes in 2003, we obtain a measure of inward tariff protection at the industry level that is comparable over the period from 1994 to 2007.

Figure 1 shows the evolution of import tariffs including several years before our sample period. A number of patterns stand out. First, tariff reduction proceeded in spurts, with large

\footnotetext{
8 Revision of the constitution in 1999, for example, improved the political environment for private entrepreneurs, while amendments in 2004 signaled better safeguards for private property rights.

9 We extend the HS-CIC concordance table constructed by the NBS to include all manufactured products (HS) and manufacturing industries (CIC) and correct several mistakes. Changes in the HS system in 2002 (affecting nearly ten percent of all product lines) and in the CIC system in 2003 required multiple concordance tables.
} 
and widespread reductions occurring between 1994 and 1997, and then again in 2002; reductions are more gradual and idiosyncratic in other years. Second, output tariffs were on average substantially higher than input tariffs, reflecting the different treatment of final goods from raw materials, intermediates inputs and capital imports. And third, by the end of the period the median output tariff was only 7.5 percent, far below the average for countries with a similar income level as China. The gap between the median output and input tariff also narrowed to less than two percentage points.

[Insert Figure 1 approximately here]

The average evolution hides important variation both across industries and within industries over time that we exploit to estimate the effects of the trade liberalization on productivity and markups. The shaded area in Figure 1 denotes the inter-quartile range for industry output tariffs, and the dashed lines the corresponding inter-quartile range for input tariffs. Industries initially differed tremendously in the protection they received. The narrowing of the two bands over time highlights the important tariff compression: For output tariffs, the inter-quartile range declined from 18-55 percent in 1994 to 6-12 percent in 2007. As a result, the extent of trade liberalization experienced by industries often differed substantially.

Non-tariff barriers (NTBs) and restrictions on foreign investment were also part of the policy landscape. Annual circulars of the Ministry of Foreign Trade and Economic Cooperation and the Ministry of Commerce provide information on the licensing of imports and exports, as well as FDI restrictions.10 In some sectors foreign firms were required to work with a domestic partner, while in others they were prohibited from entering entirely. In Figure 2, we graph the fraction of industries that contain at least one 8-digit product line subject to some form of FDI restriction. The number declined from a high of 87 (out of 424 industries) in 1995 to 47 in 2007, with most of the liberalization happening at the moment of WTO entry. The decline is more rapid for the restrictions than for outright prohibitions, which made up one-fifth of the total in 2007. The total number of industries subject to some form of import licenses also fell, but the decline was both less monotonic and more drastic. After a brief rise from 15.3 percent in 1997 to 22.6 percent in 2000 , it declined to only 1.2 percent in 2007.

[Insert Figure 2 approximately here]

10 The Chinese government first published the Catalogue for the Guidance of Foreign Investment Industries in 1995. It was revised in 1997, 2002, 2004, 2007, 2011 and 2014. It classifies all industries, which we mapped into the CIC classification, into "encourage", "permit", "restrict" and "prohibit" categories. 
In our analysis, we use import tariffs as the key explanatory variables because they provide the most accurate and detailed information on trade openness. The overall pattern of trade liberalization is apparent for all three indicators shown in Figure 2. In the cross-section, the correlation between the different forms of protection is significantly positive in 1997. By 2007, however, the correlations between tariffs and either NTBs or FDI restrictions had become very weak, reflecting the convergence of import tariffs to a fairly uniform level in all industries and the dwindling importance of recorded NTBs.

\section{Endogeneity of tariffs}

There are two endogeneity concerns when using tariffs as explanatory variable for the extent of trade liberalization. A first concern is reverse causality. A negative association between tariffs and productivity might not be due to lower tariffs inducing improved productivity, but to policymakers lowering tariffs selectively only in industries that are able to compete with less expensive imports, for example, in industries experiencing a productivity spurt. A second concern is misattribution. Industry characteristics that are merely correlated with tariff cuts might be the real reason for the subsequent productivity growth.

There are several reasons why the first of these concerns is unlikely to be a serious problem. The low remaining variation in tariff rates by 2007 implies that there was little room for policy discretion in tariff reductions. The inter-quartile range for output tariffs was only 6-12 percent at the end of the sample period and for input tariffs the range was even narrower, 5-7 percent. The average import tariff declined from 44 to 10 percent between 1992 and 2007, but equally remarkable was the decline in the standard deviation across industries from 28 to 7 percent. Moreover, the partial correlation between tariff rates in the first and last year is extremely high at 0.70 . An industry's relative protection in 2007 is well explained by its initial protection.

Figure 3 shows this pattern explicitly, plotting the change in import tariffs between 1992 and 2007 on the vertical axis against the initial level on the horizontal axis. The dispersion of protection across industries is extremely wide in 1992, with nine industries receiving protection of more than 100 percent. By 2007, only a single industry had an import tariff above 40 percent and only nine were above 25 percent. The relationship between tariff reduction and initial protection is almost one-to-one, as can be seen from the close fit with the dashed line, which has a slope of -1 .

[Insert Figure 3 approximately here] 
The bottom panel of Figure 3 shows that there is more heterogeneity in the extent of tariff reductions in the post-WTO period (2001-2007). There could be some policy endogeneity, but only in an expected sense as tariff cuts after 2001 were already fixed in the WTO accession agreement. For these cuts to depend on an industry's strong productivity evolution, this performance either had to be predicted at the time of negotiations or, more plausibly, actual tariffs had to deviate from the agreed rates. We observe some deviations and to rule out this form of policy endogeneity, we use the rates from the accession agreement, which were mostly fixed by 1999, as instruments for the actual tariff rates.11 We report this first stage regression for the period between 2002 and 2007 in Column (5) of Table 1. The maximum tariff level is a good predictor of the actual tariff and the coefficient below one suggests that tariff reductions were often implemented earlier than the accession agreement mandated.

To investigate more formally whether industry variation in trade liberalization is related to past performance, we regress changes in tariffs between 1998 and 2007 on initial productivity, similar to Topalova and Khandelwal (2011). Because we estimate productivity separately for each two-digit sector, comparisons of productivity levels are only valid within these sectors. We resolve this in two ways. First, when using the initial level of TFP in 1998, we include twodigit sector dummies such that we only compare productivity levels between 4-digit industries within the same 2-digit sector. Second, we use TFP growth in the three years prior to 1998, exploiting variation in pre-1998 productivity trends across all 4-digit industries.

The baseline results in columns (1) and (2) of Table 1 show that neither of these two measures of initial productivity is correlated with the subsequent tariff cuts. Only when both measures are included simultaneously, in column (3), are the point estimates marginally significant, but they are of opposite signs and equally important in size (we report beta-coefficients, normalizing both variables by their standard deviation). More productive industries receive deeper tariff cuts, but industries experiencing faster productively growth before 1998 receive smaller tariff cuts afterwards. The latter relationship is in line with the expressed goal of using WTO entry as a catalyst for reforming lagging sectors in manufacturing, and it works against the reverse causality concern in the analysis below.

[Insert Table 1 approximately here]

11 This instrument does not resolve endogeneity caused by policymakers' correct anticipation of future performance when negotiating the WTO agreement. However, the inclusion of industry-fixed effects, a substantial lag between the negotiations and much of our sample period, and great uncertainty regarding industries' future performance in the Chinese high-growth environment makes this a secondary concern. 
Once we include additional controls, in column (4), the correlation between tariff cuts and initial productivity disappears entirely. These controls include previous and concurrent export performance, indicators for the type of good produced (intermediate, capital or consumer goods), and a number of US and Chinese industry characteristics that are predictive of crossindustry tariff variation in 1998. As noted above, a potential concern is that industry characteristics correlated with tariffs cuts might be the real source of the subsequent productivity growth. Exports, for example, grew rapidly following WTO entry and a strong export performance of an industry could raise its domestic productivity. However, we do not find any relationship between sectoral differences in export growth and tariff cuts. In fact, very few industry-level characteristics are correlated with the tariff changes. In the performance regressions below, we will control for industry-fixed effects at the 4-digit level, as well as employment levels and shares of state and foreign-owned firms.

\section{Empirical framework}

\section{A. Estimating equation}

To identify the effects of tariff reductions, we follow the two-step approach of Pavcnik (2002). We first construct the performance measures $y_{i t}$, starting with firm-level price-cost markups and productivity. We next regress them on the indicators of trade openness, i.e. oneyear lagged output and input tariffs at the industry level,

$$
y_{i t}=\alpha_{O} \text { output tariff }_{s t-1}+\alpha_{I} \text { input tariff }_{s t-1}+Z_{s t} \gamma+\gamma_{t}+\gamma_{i}+\gamma_{s}+\epsilon_{i t},
$$

where we include a vector of time-varying industry controls $\left(Z_{s t}\right)$ and year-fixed effects $\left(\gamma_{t}\right)$. We include firm-fixed effects $\left(\gamma_{i}\right)$ and in the few cases where the sample contains firms that switch industries we also include industry-fixed effects $\left(\gamma_{s}\right)$. In the post-WTO period we instrument the applied import tariffs with the pre-determined maximum tariffs rates in the WTO agreement, as discussed above.

Because of the firm-fixed effects, the coefficients of interest are identified from the correlation between the average growth rate of $y_{i t}$ across all firms in industry $s$ and the change in import tariffs applied to the output or inputs of industry $s$. The year-fixed effects control for the average growth rate for the entire manufacturing sector and the average evolution of import tariffs. We investigate robustness by estimating a specification that introduces 2-digit sector by year interaction fixed effects, in which case only the deviations across 4-digit industries 
within each 2-digit sector contribute to the identification. In a final set of regressions, where the objective is to investigate where in the productivity distribution new firms enter, we omit the firm-fixed effects.

We use a variation of equation (1) without firm-fixed effects for the industry-level regressions where the performance variables $y_{s t}$ are price indices and four decomposition terms for the growth in average markup or productivity. We calculate these decompositions over two subperiods and pool them such that we can use industry-fixed effects. Identification still comes from the correlation between industry-variation in growth rates and tariff changes. Finally, we can estimate the same regression using product-level imports as a dependent variable with product-fixed effects included.

Standard errors in firm-level regressions are clustered two-ways: (1) At the industry-year level since the explanatory variables of interest only vary at that level; and (2) at the firm level to account for possible serial correlation in the dependent variable. In regressions using industry-year or product-year observations, standard errors are clustered at the industry or product level.

\section{B. Markup}

To measure the effects of trade liberalization on markups, we calculate the price-cost ratio as in De Loecker and Warzynski (2012):

$$
\mu_{i t}=\left(\frac{p^{Q}}{M C}\right)_{i t}=\frac{\beta_{m}}{\tilde{s}_{i t}^{M}}, \quad \text { with } s_{i t}^{M}=\frac{\exp \left(m_{i t}^{n}\right)}{\exp \left(r_{i t}-\hat{\epsilon}_{i t}\right)}
$$

The markup is the ratio of the output elasticity $\beta_{m}$ for a variable input to the corresponding adjusted revenue share $s_{i t}^{M}$ (using the nominal variables $r_{i t}$ and $m_{i t}^{n}$ ). An important advantage of this approach is that it provides a measure of firm performance that varies with market power without having to make functional form assumptions on demand or behavioral assumptions on competition. We use materials and intermediate inputs as our variable input because firms can adjust this more flexibly than either capital or labor use, and it is least likely to suffer from measurement error.

The intuition for equation (2) is as follows. Holding other inputs fixed, the marginal product of material inputs declines in the intensity of their use. In a competitive situation, the firm faces a fixed output price, and maximizes profit at output level at which the marginal value product of material inputs equals their price. At this point, the output elasticity equals the revenue share 
and the ratio in (2) equals one. In contrast, an output elasticity larger than the revenue share indicates that the firm decided not to increase material input use to exploit fully its marginal productivity; instead, the firm exercised market power and raised the final good price, producing a lower quantity of output and purchasing less inputs.

With a Cobb-Douglas production function, the numerator of equation (2) is simply the coefficient on material inputs. If we use $\ln \left(\mu_{i t}\right)$ as the dependent variable, the numerator is absorbed by the industry or firm-fixed effects and the expression simplifies to $-\ln \left(s_{i t}^{M}\right)$. We still have to estimate the production function to calculate the markup in order to adjust the material share by the idiosyncratic productivity shock $\hat{\epsilon}_{i t}$, which is recovered in the first stage of the production function estimation. As a result, we are not able to calculate the markup in the first year of the sample. With a more flexible production function, the log-markup would additionally depend on a firm-specific output elasticity $\ln \beta_{m i}$, but even the average of this elasticity over the sample period would be absorbed by the firm-fixed effect. We only fail to control for changes in the firm-specific output elasticity $\ln \left(\beta_{m i t} / \bar{\beta}_{m i}\right)$ that are correlated with the trade liberalization.

\section{Productivity}

Our second dependent variable is revenue productivity (TFPR), obtained as a residual from a gross-output production function estimated separately for each 2-digit sector. Nominal output and material inputs are deflated by industry-level price indices. As mentioned, we assume a Cobb-Douglas functional form for the underlying physical production function:

$$
q_{i t}=\beta_{k} k_{i t}+\beta_{l} l_{i t}+\beta_{m} m_{i t}+\omega_{i t}+\epsilon_{i t}
$$

In the absence of firm-level output and input prices, we rewrite it using deflated nominal variables:

$$
\tilde{r}_{i t}=\beta_{k} \tilde{k}_{i t}+\beta_{l} l_{i t}+\beta_{m} \tilde{m}_{i t}+\left(p_{i t}^{Q}-\overline{p_{t}^{Q}}\right)-\beta_{m}\left(p_{i t}^{M}-\overline{p_{t}^{M}}\right)+\omega_{i t}+\epsilon_{i t},
$$

where deflated revenue $\tilde{r}_{i t}$ equals $q_{i t}+p_{i t}^{Q}-\overline{p_{t}^{Q}}$, with a similar expression for materials. $\tilde{k}_{i t}$ is a measure of real capital using a capital deflator.12 Employment is measured by the number of workers. 
We distinguish between a persistent productivity term $\omega_{i t}$ and an idiosyncratic term $\epsilon_{i t}$ that captures transitory productivity shocks and measurement error. As firms condition input decisions on $\omega_{i t}$, consistent estimation of (3) faces an endogeneity problem. We implement the GMM estimator of De Loecker and Warzynski (2012) that implicitly inverts the material input demand equation to obtain a proxy for unobserved productivity. Relying on the persistence in productivity, we use lagged material inputs to make sure the exclusion restriction is satisfied. Importantly, as argued by De Loecker (2013), we explicitly introduce the policy variables of interest in the equation governing the evolution of firm-level productivity, which makes the tariffs also appear in the control function. This proved vital to obtain reasonable point estimates, which is intuitive since firms' input demand (or investment) is likely to shift with trade liberalization.

It is well known that using nominal variables introduces firm-specific price deviations in the error of equation (3), which leads to a second endogeneity problem. The lack of output prices can be overcome with an explicit demand function, as in De Loecker (2011), or with additional data, as in $\mathrm{Lu}$ and $\mathrm{Yu}(2015)$. However, information on the full price vector of inputs is rarely available and even then one needs to observe the exact input mix for each firm to construct an appropriate price index. Multiproduct firms pose additional problems, as discussed by De Loecker and Goldberg (2014), since the output mix needs to be observed as well. When input expenditure is only recorded at the firm level, estimation is only possible if all products are produced with the same production technology.

Several factors are likely to limit the severity of this problem. First, we use a detailed price deflator at the 4-digit industry level that already captures price evolutions common to all firms in a narrowly defined industry. Estimates below show that the industry price index adjusts strongly to tariffs and these effects are already controlled for. Second, differences between firm-specific deviations from output and input price indices appear with opposite signs in the estimating equation. To the extent that firms paying higher input prices also charge higher output prices, the two terms cancel out. In the absence of input prices, it might be better not to control for either form of price variation than only control for output prices (De Loecker and Goldberg, 2014). Third, consistent estimation is not a problem if firm-specific price variation is a monotonic function of the same state variable that also determines the firm's input choices. In the estimation, the non-parametric proxy for unobservable productivity differences already controls for this factor, as shown explicitly in De Loecker et al. (2016). Fundamentally, it assumes that the unobservable firm heterogeneity can be represented by a single-dimensional state variable. 
Firm-level growth in deflated productivity, i.e. the residual from equation (3), is an estimate of the following expression:

$$
\Delta T F P R_{i t}=\Delta \omega_{i t}+\Delta \epsilon_{i t}+\left(\Delta p_{i t}^{Q}-\Delta \overline{p_{t}^{Q}}\right)-\beta_{m}\left(\Delta p_{i t}^{M}-\Delta \overline{p_{t}^{M}}\right)
$$

By construction this expression is only correlated with industry-level variables such as output or input tariffs through the first term on the right hand side if we use the same weights in the regression as in the construction of the sectoral price indices. In that case, the price deviations are mean zero for each industry-year and guaranteed to be uncorrelated with industry-level tariff rates. Hence, it is possible to draw inferences about the productivity effects of tariff declines independently from effects on markups.13 In the discussion of results we will thus interpret the effects of changes in industry-level tariffs on TFPR as efficiency effects, even though the efficiency level of firms is not identified.

\section{Relationship between markup and productivity effects}

A similar time-difference of the markup evolution amounts to

$$
\Delta \ln \mu_{i t}=\Delta p_{i t}^{Q}-\Delta \operatorname{MC}\left(\begin{array}{c}
- \\
\Delta \omega_{i t}, \Delta p_{i t}^{W}, \Delta q_{i t}
\end{array}\right)
$$

with $\Delta p_{i t}^{W}$ representing a vector of all factor price changes. If the production function takes a constant returns-to-scale Cobb-Douglas form and all inputs are variable in the short run, the change in the log-markup simplifies to $\Delta \omega_{i t}+\Delta p_{i t}^{Q}-\beta^{W} \Delta p_{i t}^{W}$, subtracting a linear combination of factor price changes using the appropriate weights from the production function.

Effects of tariff cuts on markups differ from the effects on productivity by the additional effects on output and input prices, which work in opposite directions. A reduction in input tariffs, for example, lowers input costs and would, ceteris paribus, raise markups. But if the firm passes some cost savings on to consumers in the form of lower prices, markups will increase by less than the decrease in marginal costs. Similarly a trade-induced productivity gain will have a smaller effect on the markup than in the productivity regression if some of its effect is passed on to consumers in the form of lower output prices.

\footnotetext{
13 Equation (4) in De Loecker and Goldberg (2014) shows the same relationship in levels. Our comparison between different industries over time is in contrast with Garcia and Voigtländer (2013) who compare exporters and non-exporters, in which case $\Delta$ refers to a difference between two types of firms. As they further assume that all firms face the same input prices, differences between firms in revenue productivity and price-cost margin are identical.
} 
Equation (5) suggests that in principle it is possible to recover efficiency effects from the total effect of tariffs on markups by subtracting the differential effect on output and input prices, which we estimate separately. We will use this to validate the estimated effect of tariff changes on productivity. In practice, several measurement issues make such decomposition less than exact. First, industry prices need to reflect correctly the average output prices charged by all firms in the sample. Compositional changes in the group of active firms due to tariff cuts need to be reflected immediately in the price indices. Second, the input price index must reflect the price faced by the average firm for its entire input bundle. Differences across firms within the same industry in their input mix makes the input price index for the industry that is constructed using input-output tables a theoretical construct that is inherently only correct on average. Third, the linear relationship between productivity, markups and input prices is only appropriate for a Cobb-Douglas production function. And fourth, if some inputs are not variable in the short run, changes in output quantities will also influence marginal costs and introduce yet another wedge between productivity and markup effects.

\section{E. Aggregation \& decomposition}

To quantify the additional effects of tariff cuts through reallocation, we decompose the change in average industry productivity or mark-up into a within-firm term and three betweenfirm terms. We combine the approach in Haltiwanger (1997), normalizing current levels of firm $i$ by $y_{s t-k}$, the average for industry $s$ in the initial period $t-k$, with time-average weights for continuing firm $\left(\bar{s}_{i}\right.$ and $\left.\bar{y}_{i}\right)$ as used by Griliches and Regev (1995). It amounts to splitting a third covariance term, containing $\Delta s_{i t} \Delta y_{i t}$ interactions, equally between the first two terms:

$$
\Delta y_{s t}=\sum_{i \in C}(\underbrace{\bar{s}_{i} \Delta y_{i t}}+\underbrace{\Delta s_{i t}\left[\bar{y}_{i}-y_{s t-k}\right]}_{i \in E})+\sum_{i t}\left[y_{i t}-y_{s t-k}\right]-\sum_{i \in X} s_{i t-k}\left[y_{i t-k}-y_{s t-k}\right]
$$

where $C, E$, and $X$ denote the sets of continuing, entering, and exiting firms, respectively, in industry s.

The decomposition in (6) is exact for an industry aggregate growth $\Delta y_{s t}$ that is defined as the change in a share weighted average of firm-level $y_{i t}$. We are not interested in the absolute magnitude of each term, but in the strength of the correlation with tariff changes, which we measure by using each term as the dependent variable in a separate regression. The first term measures within-firm growth and should mimic results from the firm-level regressions. The 
second, between-firm term, contributes positively to aggregate growth if trade liberalization helps firms with above average $y_{i t}\left(T F P R_{i t}\right.$ or $\left.\ln \mu_{i t}\right)$ to increase their market share. The third, the entry term, contributes positively if entrants tend to have higher levels of $y_{i t}$ relative to incumbents in liberalized sectors. The fourth term, measuring the exit margin, makes a positive contribution if trade liberalization disproportionately forces the least productive or lowest markup firms to exit.

\section{Data}

We use annual data for 1998-2007 that includes information for all state-owned industrial firms and non-state owned firms with sales above 5 million RMB. The information is collected through annual surveys by China's National Bureau of Statistics (NBS) and discussed in detail in Brandt et al. (2014). Aggregates for employment, sales, capital, and exports for these firms match almost perfectly the totals reported annually in China's Statistical Yearbook. Compared to the universe of firms observed in the 2004 Economic Census, our sample of above-scale industrial firms represents the bulk of industrial activity in China. In 2004, they accounted for 91 percent of the gross output, 71 percent of employment, 97 percent of exports, and 91 percent of total fixed assets.

Our final dataset is an unbalanced panel that increases from 145,511 firms in 1998 to 311,323 firms in 2007. As firm IDs often change due to restructuring or M\&A activity, we utilize information on firms' name, industry, and address to establish links over time. Only four percent of the links rely on this additional information, but one-sixth of the firms that are observed for more than one year experience a change in their official ID at some point. To estimate firm-level productivity we use the following variables: total production (output), use of materials, intermediates and service inputs (materials), total employment (labor), and the real capital stock constructed from fixed assets information using the algorithm discussed in Brandt et al. (2012).

We utilize information on firms' registered type (qiye dengji zhuce leixing) to construct ownership categories. For types that include firms with mixed ownership, we assigned the category with the largest ownership share in registered capital. Firms are grouped into three categories: state, foreign, which includes subsidiaries of firms from Hong Kong, Macao or Taiwan (HMT), and private, which includes township \& village enterprises and joint ventures with local governments. Other firm characteristics used in the analysis are the location (province), year of establishment, and export status. 
To deal with changes in the Chinese Industry Classification (CIC) codes in 2003, some industries are merged to obtain a consistent classification over the entire sample period.14 The industry characteristics used in Table 1 are merged in at this level. Chinese industry characteristics are constructed from the information in the 1995 and 2004 industrial censuses. US characteristics are taken from the FTC and described in Ravenscraft and Wagner (1991). The trade policy instruments that were discussed before-tariffs, non-tariff barriers, and FDI restrictions - are aggregated to the same level. Import flows by trade type (ordinary or processing trade) and type of importer (regular or trading firm) are from China's Customs Office and are aggregated to the 6-digit HS product level.15

\section{A. Price deflators}

To construct an output deflator at the most detailed level possible, we use information from the 1998-2003 firm surveys. For these years, firms were asked to report the value of their output in nominal terms as well as in real prices using a set of 'reference prices' provided by the NBS.16 The ratio of nominal to real output provides a firm-specific index of a firm's price level in that year relative to the base year of the reference prices. The change in this index between two years measures the firm-specific price change, which we average to the four-digit industry level. We drop as outliers those observations for which the price change differs by more than half of the standard deviation from the mean, or approximately $15-25 \%$ of observations. We then recalculate the weighted average price change for each industry, using current output weights. Annual price changes are linked over time to construct an output deflator for each of the 425 four-digit industries.

We extend the series forward for the remainder of the sample period, to 2007, using a twodigit (39 industries) ex-factory price index constructed by the NBS that we take from China's Statistical Yearbook. When investigating the impact of tariff reductions on domestic prices, we show results for two alternative price series as robustness checks: using the two-digit NBS price series for the entire sample period and using a less conservative deflator constructed from the firm-level information, but only dropping outliers that see a price change that is at least one

\footnotetext{
14 The industry concordance as well as deflators, tariff rates, the input-output table, and programs to construct the firm panel and real capital stock are available online at http://feb.kuleuven.be/public/N07057/CHINA/ appendix/.

15 Trading companies are identified by the following words in the firm name: 贸易, 进出口, 经贸, 工贸, 外经, 外贸.

16 Before 1993, most industrial firms only reported output in reference prices; from 1993 onwards, the NBS additionally asked to report current price output. In 2004, the NBS stopped collecting the constant price output series, claiming that as industrial firms' innovation accelerated, many new varieties of products emerged, and frequently determining and updating all constant price became too costly.
} 
standard deviation different from the mean change (dropping $8 \%$ of observations). Results in Table A.1 in the Appendix show that all three series are highly correlated at the 2-digit level.

The input price deflator for each industry is constructed as a weighted average of the output deflators of all manufacturing industries, using as weights the input shares from the 2002 National Input-Output (IO) table. As the IO table only distinguishes 80 industrial sectors, which is less detailed than the industry classification used in the firm-level data, we constructed a concordance table linking the two classifications. We calculate an aggregate output price index for each IO sector as an output-weighted average of the underlying industry prices and then obtain the input price deflator for each IO sector as an input-share weighted average of these output deflators. The same input weights are used to construct input tariffs for each sector based on the output tariffs for all manufacturing sectors.

\section{Results}

\section{A. Imports and domestic prices}

We measure industry variation in the extent of trade liberalization by tariff reductions rather than the resulting import growth. One reason is that tariffs immediately reflect the policy change and firms might change their behavior anticipating future import growth. The change in import penetration is likely to have a more gradual effect on domestic firms. A second reason is that tariff reductions can trigger domestic price responses, in which case the observed import growth underestimates the increased competition. The evidence for the Brazilian cement industry in Salvo (2010) provides an extreme illustration. Following a reduction in import tariffs, limit-pricing by a domestic cartel kept imports out entirely, even though competitive pressure greatly increased and profits fell.

Estimates in panel (a) of Table 2 use imports at the product level, aggregated from detailed trade transaction records at the firm-product-destination level from China's Customs, as dependent variable. They show that following China's WTO entry, tariff reductions lead to strong import growth. We excluded imports entering China as processing trade that was exempt from import duties, approximately one half of the total, and focused on growth in ordinary trade.17 Using the same specification at the product level as we use below for markups and productivity, we find an average semi-elasticity of tariffs on import flows of -3.1. The response

17 The effects reported in Table 2 are for imports not entering through trading companies, which represent a significant but declining portion of imports over this period. Results are qualitatively similar for trading companies which are included in the regression, but are allowed to be affected differentially by import tariffs. 
is highest (equal to -4.3) for intermediate inputs, the largest product category, and slightly smaller (equal to -2.8) when we do not instrument the tariff change. With ordinary trade imports growing at an annual rate of $13.7 \%$, the average tariff decline of $1.2 \%$ per year accounts for approximately one quarter of the import growth. 18

[Insert Table 2 approximately here]

With trade liberalization, domestic firms not only lose market share to imports; tariff cuts also lead to lower domestic prices. This is shown in panel (b) of Table 2 using similar regressions, now using the domestic (output) deflator as dependent variable. The estimates in row (i) are for the benchmark deflator, using detailed 4-digit price deflators from Brandt et al. (2012), which are available between 1998 and 2003, extended to the end of the sample period using the 2-digit deflators that the Chinese NBS calculates. The estimates in column (ii) use an alternative price series where fewer outliers are dropped in the construction of the detailed deflator. Row (iii) uses the more aggregate 2-digit price deflator throughout.

The point estimates indicate that the effect of tariff cuts on domestic prices is both large and estimated relatively precisely. A one-percentage point reduction in import tariffs leads on average to a 0.30 percent price reduction. Given that import penetration averages only 10 percent, this strong price response suggests not only a large pass-through of tariff declines into the prices of imported goods, but also that domestic producers adjust their local prices in response to these cuts. 19

The estimates are notably higher for some product categories than for others. In columns (2)(5), we report estimates for separate product categories defined using the Broad Economic Classification of goods.20 Prices of materials (column 2) and intermediate inputs (column 3) are most sensitive to tariff changes, suggesting that price competition is strongest in those sectors. Recall that the import response was also most pronounced for intermediate inputs. Prices for capital goods (in column 4) are less responsive to tariffs and for consumer goods there is no significant effect over the full sample period using any of the three deflators. Brandt and Thun (2010) provide evidence for China that suggests domestically produced and imported

18 Table A.4 in the online Appendix contains robustness checks for the estimates using imports and prices as dependent variables; Table A.5 contains robustness checks for the estimates in Table 3 that use firm-level markups and productivity as dependent variables.

19 Note that competition can lower prices in two ways: either, direct by lowering markups, or indirectly by triggering actions that lead to efficiency gains.

20 The BEC categories are partitioned into four product groups as follows: materials $(111,21,31)$, intermediate goods (121, 22, 322, 42, $53)$, consumer goods $(112,122,61-63)$, and capital goods $(41,51,52)$. 
capital or consumer goods often compete in different market segments, which helps shelter domestic firms from import competition.

\section{B. Effects of trade liberalization on firm-level markups}

A price reduction following a tariff cut can be due to lower markups, lower input prices, or higher efficiency. As we constructed separate variables to measure tariffs applied to each industry's output and inputs and we estimated firm-level markups and productivity as separate performance variables, we now investigate the relative strength of different mechanisms using the specification of equation (1).21 We include firm-fixed effects such that all coefficients are identified from changes over time. Results are based on a sample of firms that did not switch between different 4-digit industries.22

In panel (a) of Table 3 we report baseline results for firm-level markups using three weighting schemes: no weights, within-industry output shares, and total output weights. With only one exception, the effects of input and output tariffs on markups are of opposite signs.23 Lowering input tariffs leads to higher markups, as expected. It directly reduces marginal costs and as long as these cost savings are not perfectly passed on to consumers, markups should increase. In the even-numbered columns, we supplement the firm-fixed effects with sector-year interaction fixed effects which greatly raises the absolute size of the point estimate. This is a mechanical result as the input tariff variable is constructed using the Chinese input-output table and only varies at the 3-digit level. More of its variation is already absorbed by the interaction fixed effects than is the case for the more disaggregate output tariffs. The mean effect of a one standard deviation reduction in input tariffs (which is now much smaller) on the firm-level dependent variable is of similar magnitude in the odd and even numbered columns. A onepercentage point decline in input tariffs on top of the average decline of the sectoral average implies a much larger change. 24

\footnotetext{
21 The production function coefficients are reported in Table A.2 in the Appendix and Table A.3 shows summary statistics on TFP growth rates and implied markups.

22 Approximately twenty percent of firms switched industry at least once over the sample period. Our motivation for dropping them is two-fold: first, for firms that switched between 2-digit sectors, their markup and productivity estimates are incomparable over time; and second, for firms switching industries it is not obvious which (lagged) tariff rates to include, which might bias our estimates.

23 Standard errors in Table 3 are clustered two-ways, at the industry-year and at the firm level. If we cluster at the industry level, the output tariff coefficient becomes statistically insignificant in the markup regression in column (3a), while remaining insignificant in columns (1a) and (2a); in the productivity regression the output tariff coefficient in column (4b) becomes insignificantly different from zero, while other coefficients remain significant, but only at a lower level.

24 We do not observe the same increase in the (absolute) input tariff coefficient in the productivity regression. The reason is that the production function parameters are estimated at the 2-digit level. In that regression, the dependent variable also sees a substantial reduction in standard error after controlling for the interaction FE.
} 
In contrast, a reduction in output tariffs leads to lower markups (positive coefficient in Table 3 ), and is the net result of two opposing effects. On the one hand, the increase in foreign competition can spur firms to implement efficiency-raising investments, which raises markups if the resulting cost savings are not perfectly passed-on. On the other hand, the pro-competitive effect of the tariff reductions is likely to depress markups as firms adjust their optimal pricing. The point estimates indicate that the latter effect dominates for large firms since the positive coefficient only turns statistically significant if we weight observations within industry by size, as we do in columns (3) and (4). Weighting industries differently as well, as happens when we use absolute output weights in columns (5) and (6), further increases the absolute magnitude of the coefficient, i.e. the markup-reducing effect.

The combined effect we estimate is smaller than the point estimate of 0.109 for India in De Loecker et al. (2016) obtained using a similar specification, but for a product-level markup. As they use a small sample with relatively large firms, the most comparable estimate is the 0.095 effect we report in column (4) which implies that each percentage point decline in the output tariff lowers the markup by 0.1 percent. The trade liberalization over the entire 1998-2007 period reduced markups by approximately $1.1 \%$ permanently. Given a median markup over all sectors of around $26 \%$, this is a rather small effect.

The estimated effect of input tariff reductions on markups goes in the other direction and is of much larger magnitude such that the average markup rises with trade liberalization, as in De Loecker et al. (2016). A point estimate of zero would indicate that the entire cost saving is passed on to customers, which we can reject for all estimates except in column (3). If there was no pass-through at all, the point estimate should equal the share of intermediates in marginal cost $(88 \%)$ multiplied by the average effect of the input tariff reduction on input prices (49\%).25 Hence, each percentage point cut in input tariffs should increase the markup by $0.43 \%$ in the absence of any pass-through. The estimate of -0.23 in (1a) (without weighting) suggests that firms retain more than half of the surplus gain, which may seem large given the strong competition we expect to prevail in many Chinese industries. However, this calculation ignores that as trade liberalization lowers input prices and thus marginal costs, a profit maximizing firm with market power is expected to raise its markup. If that is the case, the estimated coefficient implies a larger rate of pass-through than calculated above.

25 A median share of intermediates in revenue of $70 \%$ with a median markup of $26 \%$ implies a cost share of intermediates of $88 \%$. 
Note that the inclusion of the input tariffs in the markup regression already controls for one effect of trade liberalization through lower input prices, but to the extent that efficiency gains raise markups, the pro-competitive effect itself will be higher than the output tariff coefficient. The results of De Loecker et al. (2016) for India do not attribute an important role for increased efficiency. As they observe firm-level prices, they can control explicitly for marginal costswhich controls for both input cost reductions and efficiency gains. As a result, their point estimate, reflecting only the pro-competitive effects, increases to 0.143 . We do not observe firm-level prices to perform a similar exercise, but as argued above we can look directly at the effect of trade liberalization on productivity to isolate any efficiency effect.

\section{Effects of trade liberalization on firm-level productivity}

The estimated effects of tariff reductions on firm-level (revenue) productivity are net of the average price evolutions in each industry. The average price responses shown in Table 2 are netted out and the remaining firm-level price deviations in equation (3) will not be correlated with industry tariffs if we use appropriate weights. We therefore focus on estimates in columns (3) to (6), which are the only effects of tariffs on productivity (TFPR) that can be interpreted as efficiency effects. All point estimates are negative suggesting that both type of tariff declines promote efficiency gains.

The most notable difference with the results for markups is that the coefficient on the output tariff is now estimated to be consistently negative, equal to -0.176 for the preferred estimator in column (3). As the output price responses to tariff cuts in Table 2 were larger than the markup responses in panel (a) of Table 3, we could already deduce that Chinese firms must have implemented efficiency-enhancing changes. Effects are slightly smaller (in absolute value) if we use sector-year interaction fixed effects, in column (4), but differences are not statistically significant for the two sets of fixed effects using any of the three weighting schemes.

It is instructive to note that point estimates on output tariffs are larger in absolute value without weights than with weights. We saw earlier that markups only fell with output tariff reductions if we weight firms by size and thus identify the effect primarily from the responses of larger firms. The more negative effects on input tariffs without weights than with weights further point to lower prices for larger firms in liberalized sectors. Small firms are thus more likely to have a positive deviation between firm-level prices and the sectoral average in more liberalized industries and the reverse for larger firms. As these price deviations ends up in the TFP variable, it will erroneously induce a stronger negative relationship between tariffs and 
TFP if each of the many small firms receives the same weight as the few large firms. This prediction is borne out in Table 1, as can be seen comparing results without and with weights. Results in columns (1) and (2) are biased downward in a predictable way.

The point estimates on the input tariffs are always estimated strongly negative, with benchmark estimates in columns (3) and (4) equal to -1.79 and -1.62 . They are much larger in absolute value than the output tariff effects. The total impact of input tariff reductions on output prices are the sum of three effects - on productivity, on input prices, and on markups - and we can use this decomposition to deduce the rate of pass-through. The estimated efficiency increase in column (4b) implies that a one percentage point reduction in input tariffs lowers output prices by 1.6 percent. Results in Table 2 implies that tariff declines show up in domestic prices at a rate of 0.30 percent for each percentage point reduction and pro-rated this should lower output prices by a further 0.26 percent. The point estimate of input tariffs on the markup of -0.73 in (4a) suggests that more of the cost savings are passed-on to consumers in the form of lower prices than kept by the firm as a larger mark-up (which totals 0.63 or $1.62-0.26-$ $0.73)$, a similar conclusion as before.

The pattern of a robust and significantly negative coefficient on output tariffs in the TFP regression even when we control for input tariffs, is in contrast with the experience of many other developing countries examined in the literature, including Brazil (Schor, 2004), Indonesia (Amiti and Konings, 2007), and India (Topalova and Khandelwal, 2011; De Loecker et al., 2016). In those countries, the effect of output tariffs on productivity becomes insignificant once input tariffs are added to the regression. Several factors unique to the Chinese manufacturing sector, such as the large scale of the internal market, its early export success in a wide variety of products, and the important presence of foreign-owned firms, are likely to lower the benefits associated with improved access to high quality imported inputs. At the same time, the presence of state-owned firms with sizable monopoly power raises the potential benefit of increasing import competition. These and other factors will be discussed below in Section 6 .

Finally, we verify whether the differential impact of tariffs on markup and productivity is consistent with the wedge that output and input prices drives between them, as illustrated by equation (5). In the constant returns-to-scale case, the difference in the effects of a tariff reduction on the markup and on productivity should equal the effect of such tariff reduction on $\Delta p_{i t}^{Q}-\beta^{W} \Delta p_{i t}^{W}$, with the last term a weighted average of input price changes for all input factors entering marginal costs. For output tariffs, the difference in effects equals 0.246 in column (3) and 0.202 in column (4). These are broadly in line with the 0.296 average effect of tariffs on prices shown in Table 2, which is the only relevant mechanism as output tariff cuts 
do not affect prices of input factors $\left(p_{i t}^{W}\right)$. For input tariffs, the coefficient is generally estimated to be more negative in the TFP regression than in the markup regression, which implies that on balance an input tariff reduction leads to a lower output price.

We can learn more about the underlying mechanisms by estimating whether trade liberalization has heterogeneous effects on different sub-groups of firms. For example, we find that efficiency gains following output tariff cuts are larger in the period after WTO entry or in coastal provinces. A difficulty, however, is that the tariff rates can be correlated with the firmspecific price-deviations remaining in the productivity estimates if different sub-groups experience systematically different price evolutions. When we allow the markup effects to differ across groups, we find for example that the pro-competitive effects were stronger in the period before WTO entry and for older firms or exporters. This is not unexpected for the latter two groups as we already found markup effects to be increasing in firm size, but it implies that we cannot interpret productivity effects anymore on these subgroups.

\section{Decomposing industry performance}

Another way to learn about the underlying mechanisms for the trade liberalization effects is by identifying how strongly the contribution to the industry-average markup or aggregate productivity of different groups of firms - incumbents, entrants, or exiting firms - correlates with the tariff rates. We accomplish this by using the four terms on the right-hand side of equation (6) as dependent variables: within-firm changes, between-firm reallocation, entry, and minus-exit. As discussed, we performed the decomposition separately for the pre-WTO and the post-WTO periods, and pool growth rates across the sub-periods and industries for a total of 844 observations. Results are reported in Table 4.

\section{[Insert Table 4 approximately here]}

For the total effects at the industry level in column (1), the signs on both tariff variables are the same as for the firm-level results in Table 3. It is intuitive that the magnitudes in the first specification with industry-fixed effects are closer to the within-industry share weighted results, while the magnitudes in the second specification with industry-year weights are closer to the earlier results using absolute output shares. Because of the linear decomposition and linear regression, the effects of tariffs on the four terms in the decomposition listed in columns (2)(5), sum exactly to the coefficient estimate on the total in column (1).

The results with industry-fixed effects that weight all industries the same are unequivocal in the attribution: The effect of output tariffs on markups, which combines the pro-competitive 
and the efficiency effect, operates almost entirely through the within-firm margin, while the increase in markups due to lower input tariffs is due to new entrants. When we weight industries by output, the overall effects become stronger and for both tariff variables incumbents and entrants play some role, but it remains the case that the behavior of incumbents dominates the output tariff effects, while entrants dominate the input tariff effect.

The effects on aggregate productivity in panel (b) are also driven primarily by the within and entry channels, but they are the result of different types of firm-level adjustments. The strongly negative output tariff coefficient in column (2c) suggests that existing firms in liberalized industries are forced to improve their efficiency, but this does not translate into improved markups, as seen in (2a). In liberalized industries, new firms enter with weakly lower price-cost markups, see (4a), which makes it harder for them to recover their entry costs. They enter, however, with higher relative productivity, indicating that the selection mechanism in these industries is more stringent.

The entry channel is particularly important when we use industry-fixed effects and implicitly assign all industries the same weight. In that case, the absolute magnitude of the coefficient on input tariffs in the productivity regression for entrants is also notable. It suggests that new firms have greater flexibility to take advantage of opportunities to improve efficiency by exploiting the availability and lower cost of imported intermediates, which are often of higher quality. We should note, however, that the decomposition of the productivity effect comes with the same caveat as before. To the extent that different groups have systematically different price evolutions, the firm-specific price deviations that remain in the productivity measures might be correlated with tariff declines. For example, we saw in panel (a) that entrants do not show the same decline in markup as incumbents (within term) in liberalized sectors. As a result, we are likely to overestimate their productivity level (as a group) which could partly explain the very negative coefficient (-0.428) for them in panel (b).

There is only one term, the "between" term in column (3), that has coefficients with opposite signs. This is most striking, but also an intuitive pattern, in the case of the input tariff coefficient in the productivity regression. Industries where input tariffs decline more, experience less of a shift in output shares from underperforming to better performing firms. The best firms are not able to grab additional market share while weaker firms maintain their share. It leads to a lower correlation between changes in output share and performance and is a drag on aggregate performance, offsetting some of the beneficial effects of input tariff liberalization.

One notable finding that holds for both dependent variables, both explanatory variables, and both specifications is the absence of any significant effects at the exit margin. In the Chinese 
high-growth context, the exit of low productivity firms contributes only marginally to aggregate productivity growth (Brandt et al. 2012). The results in column (5) further indicate that this contribution is almost entirely uncorrelated with tariff rates. The competitive selection mechanism (e.g. Melitz, 2003) predicts that with lower output tariffs, the least productive firms will be forced to exit as they lose market share to imports and cannot cover their fixed cost of operation anymore. The negative coefficients on the output tariffs in the regression using the negative of the exit term as dependent variable, in $(5 c)$ and $(5 d)$, are consistent with this mechanism, but the highly insignificant point estimates indicate this channel is extremely weak.

Government behavior may have prevented the exit mechanism from playing its usual role, especially in strategic and pillar sectors. China 2030, a joint report from 2013 by the World Bank and China's Development Research Center documents the institutional constraints on exit of both state-owned and other enterprises. After the establishment of the State-owned Assets Supervision and Administration Commission (SASAC) in 2003, the downsizing in the state sector that was prominent in the late 1990s and early 2000s more or less stopped.

\section{Discussion of underlying mechanisms}

\section{A. Pro-competitive effects of output tariff reductions}

The direct pro-competitive effect of imports through their downward pressure on domestic price-cost margins is easy to understand and a widely expected consequence of trade liberalization. This prediction has been derived under a number of setups. Levinsohn (2003) uses an oligopoly model that includes a market conduct parameter and a single local demand elasticity. Melitz and Ottaviano (2008) assume monopolistic competition and a linear demand system with horizontal product differentiation. Trade liberalization and the resulting import increase shifts the residual demand curves of surviving firms down, who respond by lowering their markup. Edmond, Midrigan and Xu (2015) use an oligopoly model and CES preferences, but assume that domestic goods are closer substitutes for each other than for imports. The implicit demand elasticity faced by domestic firms depends on an industry's import penetration and the elasticity increases following trade liberalization. Firms adjust by lowering their markups. In their application to Taiwan, this price disciplining effect dominates the overall welfare effects from trade and is almost entirely due to industries with only one or two domestic firms.

Trade liberalization can have an indirect, but opposing effect on the price-cost markup. If it lowers the marginal cost of surviving firms, through lower input prices or efficiency gains, there 
can be an offsetting, upward pressure on markups if price elasticities are lower further down the demand curve (De Loecker et al. 2016). Alternatively, if it leads to the exit of less productive, high marginal cost firms that tend to charge low markups, the reallocation of market share to more productive firms will also increase the average markup (Arkolakis et al. 2015).

Our finding that output tariff reductions are associated with lower markups indicates that these indirect effects might mitigate the direct markup-reducing effect, but they do not overturn it.

\section{B. Increased imports of intermediate inputs}

The recent trade literature stresses an entirely different channel, namely that trade liberalization can raise domestic productivity through an input effect. Halpern, Koren, and Szeidl (2009) describe two static sources of gains from trade. First, quality advantages of imported inputs might not be entirely reflected in their price. Second, a complementarity in production can raise the aggregate production function in a love-of-variety sense. A third, dynamic benefit is described in Goldberg et al. (2010). They adopt a production structure from endogenous growth models with a domestic production cost that declines in the number of imported input varieties. When the range of imports expands following trade liberalization, the domestic industry endogenously raises its productivity and is able to introduce new products. De Loecker and Goldberg (2014) show that in a simplified model this input mechanism introduces an additional term in the production function. This unobservable term is increasing in the number of imported intermediates and ends up in the residual of the production function and thus in measured productivity.

For China, the results in Table 3 indicate a strong link between input tariff cuts and firm-level productivity and results in Table 4 suggest that at the industry level the effect is of a similar magnitude as the effect from output tariff cuts. This is in contrast with findings for other developing countries where most of the impact of trade liberalization worked through imported intermediates. We can look directly at the relative increase in the use of imported inputs using a dataset that matches the detailed trade transactions in China's Customs records to the firmlevel sample.26 We rely on the BEC classification to identify imports that are unprocessed or processed intermediate goods (categories 121, 22, 42, and 53) or materials (categories 111, 21

26 In 2006, approximately one half of total imports by value are accounted for. The balance is imports by firms that could not be matched, including trading firms that act as agents for firms importing indirectly and imports by non-manufacturing firms such as retailers. Over time, the role of trading companies declined as more firms obtained direct trading rights. As a result, the statistics in Table 5 might even overestimate the increase in both the fraction of firms using imported intermediate goods and their share of inputs. 
and 31). We use this information in two ways: first, to estimate the fraction of manufacturing firms that use imported inputs, and second, to calculate the share of intermediate input use reported in the firm-level data that consist of imports.

\section{[Insert Table 5 approximately here]}

The estimates in Table 5 illustrate that in spite of a huge increase in total Chinese imports, the importance of imported intermediate inputs remains very low for Chinese manufacturing firms. The percentage of firms directly importing intermediate inputs increased only slightly from 9.6 to 10.9 between 2000 and 2007. A disproportionate share of this increase comes from firms in the processing trade regime. Their inputs enter the country duty-free and do not benefit from the reduction in input tariffs.27 It is likely that the type of inputs that these firms require is not as easily found domestically.

The share of imported intermediates in total inputs across all firms that we were able to match even decreased from 29.1 to 27.3 percent over the same period. It is consistent with the evidence of increased domestic sourcing by Chinese firms in Kee and Tang (2016). Less than 10 percent of inputs enter through the ordinary trade regime, facing import duties, and this share barely increased. It is unlikely that access to imported intermediates is the dominant channel through which the estimated productivity effect is realized. The share differs hugely across ownership types and firm-level regressions similar to those reported in Table 2 indicate that imports of private firms engaged only in ordinary trade are the most responsive to tariff cuts. However, imported inputs represent on average only 1 percent of their total input use and thus cannot account for much of their productivity growth.

In panel (c) we report a similar calculation, but now reflecting the share of imported intermediates for the entire manufacturing sector, i.e. not limited to the matched sample of firms. We divide aggregate imports for all BEC categories of intermediate inputs and materials by total input use in manufacturing.28 This overall share is virtually unchanged over the period, but for ordinary imports it increases modestly from 7.2 to 7.5 percent. The share of imports is lower for the entire manufacturing sector than for the matched sample, but the relative importance of ordinary trade imports is higher. Both patterns are intuitive since more important

27 The sum of the two forms of trade in columns (2a) and (3a) exceeds the total in column (1a) because some firms import under both regimes.

28 To calculate total input use in manufacturing, we use the sum of inputs over all firms in the NBS firm-level sample, but that underestimates the total due to the exclusion of below-scale firms. We construct a second estimate based on national accounts data, but rely on an estimate of the value added to gross output ratio. If this increases over time, as shown in Kee and Tang (2016), it overstates growth in input use. To average out both biases, we use a geometric mean of both estimates for the denominator. 
importers are more likely to be matched. Most importantly, the key finding is unchanged: Imported inputs that are subject to import tariffs were not very important in 2000 and this changed little following the decline in input tariffs.

\section{Agency Issues}

A finding unique to the Chinese context is that both the firm-level and sector-level analysis point to within-firm improvements in productivity following an output tariff reduction. As increased competition squeezes markups and threatens firms' survival, it should induce firms to make productivity-enhancing changes. The literature has considered several channels through which these type of efficiency gains could be realized, such as the utilization of "trapped factors" (Bloom et al. 2011), accelerated adoption of new technology (Ederington and McCalman, 2009), or a greater willingness of the workforce to accept changes to work practices (Schmitz, 2005).

Yet another channel are changes in the incentive structure and equilibrium effort level of managers in models with agency costs, as in Schmidt (1997), Raith (2003), and Chen (2014). Given the well-documented problems with incentivizing managers in state-owned enterprises, we expect this channel to be especially important in a transition economy like China. In the NBS data we observe the name of the legal person representative of most firms, typically the top manager which we will denote by CEO.29 This information allows us to construct an indicator for the replacement of top managers and test whether competition leads to changes in the incentive structure they face.

In theory, the relationship between competition and the optimal incentive scheme is ambiguous. Schmidt (1997) argues that a "threat-of-liquidation effect" and a "value-of-a-costreduction effect" can have opposing effects. The first effect of increased competition is to increase the risk of bankruptcy which raises the expected cost for a manager of providing suboptimal effort. The second effect reflects that conditional on survival, the potential value of cost-saving innovations is likely to decrease with competition due to a lower market share or profit margin. When the manager's participation constraint binds, the first channel dominates and tougher competition unambiguously improves incentives for effort. Raith (2003) further shows that depending on the form of competition and exit options, the value of a cost reduction could even increase with competition, further strengthening the positive effect on effort.

29 For three years, 1998-2000, the NBS data provides in addition to the name also the title of the "legal person representative". Only $16 \%$ of observations list the chairman of the board of directors (董事长), while more than $80 \%$ list the general manager (总经理 or 厂长). 
Before investigating the impact of increased competition on CEO turnover, we first compare performance, measured here by output growth or firm survival, between state-owned and privately-owned firms. We expect more severe agency problems for state-owned enterprises (SOEs) and estimate how the performance gap varies with output tariffs. Results in column (1) of Table 6 show that SOEs tend to grow more slowly than private firms and the difference increases with the level of tariff protection. The estimates in column (2) further indicate that SOEs have a lower survival rate and, importantly, this difference increases with tariff protection. A higher likelihood of exit following trade liberalization provides increased incentives for effort provision for managers in private firms, but this mechanism is not operating for SOEs. Lingering soft budget constraints for the SOEs help explain their weaker growth performance after trade liberalization, as shown in column (1).

[Insert Table 6 approximately here]

The results in columns (3) and (4), however, suggest that the government chooses to strengthen direct oversight of management in SOEs. In the absence of an automatic effect on effort through a greater risk of bankruptcy, they adjust the incentive scheme for CEOs when an industry is liberalized. We measure performance-incentives with the probability of replacing a firm's legal person representative when performance is bad. For a dummy dependent variable that indicates CEO turnover, we find a negative coefficient on output growth as well as on output growth interacted with the SOE dummy. Weaker growth is associated with a higher likelihood of CEO turnover on average, and especially for SOEs.

The specification reported in column (4) adds interactions of all variables with the output tariff. For private firms, the negative point estimate on the interaction between growth and tariffs indicates that higher competition (lower tariff) weakens the association between firm growth and the likelihood of CEO replacement. The increased likelihood of bankruptcy, see column (2), already provides sufficient effort incentives after liberalization. For state-owned firms, however, the triple interaction term has a positive coefficient and outweighs the negative effect. For these firms, increased competition strengthens the association between firm growth and the likelihood of CEO replacement. It confirms the hypothesis that firms suffering from more severe agency problems adopt higher-powered incentive schemes to induce effort when competition increases. 30

30 Similar patterns have been documented in other contexts where the competitive environment varied across industries, e.g. Giroud and Mueller (2010) and Cuñat and Guadalupe (2009). 


\section{Productivity levels of new entrants}

A notable finding from the decomposition in Table 4 is the strong correlation between output tariff reductions and the contribution of new entrants to industry TFP growth. This effect could work through higher entry rates or through the average productivity level of entering firms. Results in Table A.6 in the Appendix show that output tariffs do not raise entry rates.31 Entry rates are high in most industries, with the differences between sectors almost entirely unrelated to tariff reductions. Only in the post-WTO period is there a positive relationship (negative coefficient), but the magnitude of the effect is very small. Even if the full extent of tariff liberalization happened in a single year, it would raise the entry rate by less than 1 percentage point.

We next compare the relative markups and productivity levels for different types of firms. In particular, we verify whether new firms enter at different points in the distribution in industries that experienced trade liberalization. We regress $y_{i t}$ on firm-status categories, distinguishing between incumbents, entrants, and exiting firms, interacted with both tariff variables. Importantly, we omit firm-fixed effects and only include industry-fixed effects (to normalize the dependent variables by industry) and firm-status interacted with year dummies (to control for changes in the sample composition and differential evolution of performance). As a result, the effects are identified from comparing levels across firms within each industry, not from the within-firm changes as in Table 3.

\section{[Insert Table 7 approximately here]}

The results in Table 7 show the same signs on all tariff variable interactions as in Table 3: an insignificant coefficient on the output tariff in the markup regression and otherwise all negative coefficients. It suggests that the mechanisms affect incumbent, entering, and exiting firms alike, although there are a few patterns to note.

Most importantly, coefficients on both tariff measures in the productivity regression are estimated to be larger (in absolute value) for new entrants. These firms adjust more strongly to the increased import competition in their output markets as well as to the availability of cheaper

\footnotetext{
31 The only systematic effect is for a decline in input tariffs to predict a lower number of active firms through reduced entry rates, but this does not help to explain the impact on industry productivity in Table 4.
} 
inputs.32 The point estimates imply that evaluated at the full tariff decline over the sample period the productivity of entrants increased on average by 4.7 percentage points relative to incumbents in the same industry following trade liberalization. 33 The difference is proportionately larger in industries that experienced larger tariff declines. For example, for industries experiencing tariff reductions of one standard deviation above the mean, the relative productivity increase is 7 percent.

A second pattern that stands out is the large and significant estimate on the input tariff for entrants in the productivity equation. Lowering input tariffs raises the productivity level of new entrants. The channel we discussed before, i.e. firms benefitting from access to a greater variety and higher quality foreign inputs, might be stronger for entrants that have more flexibility in adjusting their production process and take advantage of new opportunities. Fan, Li and Yeaple (2015) propose a complementary mechanism. In their model input tariff reductions provide incentives to upgrade product quality and they provide empirical evidence for this in the case of Chinese exporters. Quality upgrades require fixed cost investments and input tariff reductions provide the resources to finance such investment through increased price-cost margins.

We estimated similar regressions as reported in Table 7 further distinguishing firms by ownership type: private, state, or foreign owned. An interesting finding is that the procompetitive effects of output tariff reductions on markups are estimated almost the same for all entrants, regardless of ownership type, while incumbent SOEs saw a smaller decline in liberalized sectors. Moreover, for exiting SOEs the coefficient on output tariffs in the productivity regression is negative and significant. In liberalized industries, these firms have a higher productivity level when they exit than in industries where protectionism remained, indicative of a more stringent selection process.

As China transitioned to a more market-based economy, the relaxation of entry restrictions was expected to generate considerable new firm entry. While entry rates do not correlate with tariff reductions, the productivity level of entrants varies positively with the openness of an industry. Access to low cost inputs makes it possible for entrants to produce with higher productivity, while lower output tariffs reduce domestic prices and raise the productivity

32 Note that the same caveat applies as for the results on the decomposition in Table 4. To distinguishing productivity from markup effects for different types of firms one needs to assume that different groups do not experience different price evolutions from the average captured by the industry price deflators. At least the markup regression does not suggest a differential effect on pricing.

33 The cumulative reduction over the entire sample period averaged to 8 and 6 percent for output and input tariff reductions, respectively, with standard deviations of 7.2 and 2.3 . 
threshold that new entrants much achieve in order be able to enter an industry profitably. A reduction in external barriers accelerated the exit of unproductive SOEs. These results are consistent with other evidence from China in Khandelwal et al. (2013), which shows that an important cost of textile quotas was their inefficient allocation. The end of the Multi-Fiber Arrangement made it possible for more efficient entrants to capture a significant share of the market and increase aggregate productivity. The influence on entry and exit patterns is but one example of how trade liberalization interacts with domestic reforms.

\section{Conclusions}

The objective of this paper has been to analyze the impact of China's domestic trade liberalization on markups and productivity. Although these two performance measures cannot be separately identified using our Chinese firm-level data, detailed price deflators allow us to distinguish the average effects of tariff cuts on both measures separately.34 We find that input tariffs cuts raise both markups and TFP, while output tariff cuts have two opposite effects: they lower markups, but raise TFP. Compared to existing estimates in the literature, the negative and significant effect of output tariff reductions on TFP, even after controlling for input tariffs, is the most novel.

While most of the empirical literature has been concerned with the effect of tariffs on continuing firms, the theoretical literature emphasizes the important role for changes at the extensive margin. Decomposing the industry-level effect reveals that in China the entry channel was critical in improving resource allocation. It contributes more than half of the total effect of tariff changes on industry-level productivity growth.

In the Chinese context, several mechanisms are important in explaining these patterns. First, for output tariff cuts, the pro-competitive effect of trade liberalization on markups dominates countervailing forces that increase markups at the firm level (due to lower marginal costs) and at the industry level (due to a reallocation of output to more productive firms with larger markups). Second, the productivity-enhancing effects of output tariff cuts can be linked to reduced agency problems amongst incumbent firms, notably SOEs, and to a more positive selection of new entrants in sectors that liberalized most. And third, contrary to other

34 A limitation of the analysis is the absence of firm-specific prices, which requires additional assumptions to estimate the production function. The detailed price deflators mitigate the measurement problem to some extent. Using weights, we are able to distinguish between effects of tariff reductions on markups and productivity, but we can only identify the average effect for each industry and we cannot distinguish effects for sub-groups of firms. 
developing countries, access to a greater variety and higher quality inputs is unlikely to be an important channel for productivity growth: Imported intermediates increased only marginally as a share of total intermediate input use. Nonetheless, lower input tariffs that raise markups contribute to productivity growth through providing additional resources for firms to implement productivity-enhancing investments.

In terms of broader implications, our results highlight a complementary role of internal and external reforms. Several features of the Chinese economy shaped the effects of trade liberalization and are worth mentioning. First, a more liberal environment for inward FDI, which facilitated learning and technology spillovers, preceded domestic market reforms. The presence of foreign-invested firms may have diminished the importance of the mechanism working through imported inputs. Second, tariff reductions were accompanied by domestic reforms to reduce the size of the state-owned sector and relax restrictions on private firm entry. Epifani and Gancia (2011) show theoretically that welfare gains from trade liberalization are more likely to be positive under free entry, while asymmetric tariff reductions might exacerbate misallocation and even reduce aggregate welfare if entry barriers are important. An industrial policy that facilitates firm entry is complementary to trade liberalization, in line with the crosscountry evidence in Freund and Bolaky (2008) and with the evidence from the removal of textile quotas in Khandelwal et al. (2013).

Our findings have implications for the welfare gains from trade. In particular, Arkolakis et al. $(2012,2015)$ show that in a broad class of models aggregate welfare gains can be captured a few sufficient statistics. However, Edmond et al. (2015) have shown that welfare gains can be far greater in models where trade reduces monopoly or duopoly power. De Loecker et al. (2016) further showed that imperfect pass-through of input tariff reductions and price-cost margins that vary with output tariffs are quantitatively important in India. Both of our findings, a within-firm productivity boost due to import competition and a pre-selection of entrants that raises their productivity relative to incumbents add to the list of factors not included in the class of models considered by Arkolakis et al. $(2012,2015)$. 


\section{REFERENCES}

Ackerberg, Daniel A., C. Lanier Benkard, Steven Berry, and Ariel Pakes (2007). "Econometric tools for analyzing market outcomes." In James J. Heckman and Edward E. Leamer (eds.) Handbook of Econometrics, Volume 6A, Elsevier.

Ackerberg, Daniel A., Kevin Caves, and Garth Frazer (2016). "Identification properties of recent production function estimators." Econometrica 83(6): 2411-2451.

Amiti, Mary and Jozef Konings (2007). "Trade liberalization, intermediate inputs and productivity: Evidence from Indonesia." American Economic Review 97(5): 1611-1638.

Arkolakis, Costas, Arnaud Costinot, Dave Donaldson, and Andrés Rodríguez-Clare (2015). “The elusive pro-competitive effects of trade.” NBER Working Paper No. 21370.

Arkolakis, Costas, Arnaud Costinot, and Andrés Rodríguez-Clare (2012). "New trade models, same old gains?' American Economic Review 102(1): 94-130.

Autor, David H., David Dorn, and Gordon H. Hanson (2013). "The China syndrome: Local labor market effects of import competition in the United States," American Economic Review 103(6): 2121-2168.

Brandt, Loren and Eric Thun (2010). "The fight for the middle: Upgrading, competition, and industrial development in China." World Development 38(11): 1555-1574.

Brandt, Loren, Johannes Van Biesebroeck, and Yifan Zhang (2012). "Creative accounting or creative destruction? Firm-level productivity growth in Chinese manufacturing." Journal of Development Economics 97(2): 339-351.

Brandt, Loren, Johannes Van Biesebroeck, and Yifan Zhang (2014). "Challenges of working with the Chinese NBS firm-level data." China Economic Review 30: 339-352.

Branstetter, Lee and Nicholas R. Lardy (2008). "China's embrace of globalization.” In Loren Brandt and Tom G. Rawski (Eds.), China's Economic Transition: Origins, Mechanisms, and Consequences. New York: Cambridge University Press.

Chen, Cheng (2014). "Import competition, agency problem, and aggregate productivity: Theory and Evidence.” University of Hong Kong Working Paper.

Cuñat, Vicente and Maria Guadalupe (2009). "Globalization and the provision of incentives inside the firm: The effect of foreign competition.” Journal of Labor Economics 27(2): 179212. 
De Loecker, Jan (2011). "Product differentiation, multiproduct firms, and estimating the impact of trade liberalization on productivity." Econometrica 79(5): 1407-1451.

De Loecker, Jan (2013). "Detecting learning by exporting." American Economic Journal: Micro-economics 5(3): 1-21.

De Loecker, Jan and Pinelopi K. Goldberg (2014). "Firm performance in a global market." Annual Review of Economics 6: 201-227.

De Loecker, Jan, Pinelopi K. Goldberg, Amit K. Khandelwal, and Nina Pavcnik (2016). “Prices, markups and trade reform." Econometrica 84(2): 445-510.

De Loecker, Jan and Frederic Warzynski (2012). "Markups and firm-level export status." American Economic Review 102(6): 2437-2471.

di Giovanni, Julian, Andrei A. Levchenko, and Jing Zhang (2014). "The global welfare impact of China: Trade integration and technological change." American Economic Journal: Macroeconomics 6(3): 153-183.

Ederington, Josh and Phil McCalman (2009). "The impact of trade liberalization on productivity within and across industries: Theory and evidence." Working Paper, University of California at Santa Cruz.

Edmond, Chris, Virgiliu Midrigan, and Daniel Y. Xu (2015). "Competition, markups, and the gains from international trade," American Economic Review 105(10): 3183-3221.

Epifani, Paolo and Gino Gancia (2011). "Trade, markup heterogeneity and misallocations." Journal of International Economics 83: 1-13.

Eslava, Marcela, John C. Haltiwanger, Adriana Kugler, and Maurice Kugler (2013). "Trade and market selection: Evidence from manufacturing plants in Colombia." Review of Economic Dynamics 16(1): 135-158.

Freund, Caroline and Bineswaree Bolaky (2008). "Trade, regulations, and income.” Journal of Development Economics 87(2): 309-321.

Fan, Haichao, Yao A. Li, and Stephen R. Yeaple (2015). "Trade liberalization, quality, and export prices." Review of Economics and Statistics 97(5): 1033-1051.

Garcia Marin, Alvaro and Nico Voigtländer (2013). "Exporting and plant-level efficiency gains: It's in the measure.” NBER Working Paper No. 19033.

Giroud, Xavier and Holger M. Mueller (2010). "Does corporate governance matter in competitive industries?" Journal of Financial Economics 95(3): 312-331. 
Goldberg, Pinelopi K., Amit K. Khandelwal, Nina Pavcnik, and Petia Topalova (2010). "Imported inter-mediate inputs and domestic productivity growth." Quarterly Journal of Economics 125(4): 1727-67.

Griliches, Zvi and Haim Regev (1995). "Firm productivity in Israeli industry: 1979-1988." Journal of Econometrics 65(1): 175-203.

Halpern, László, Milós Koren, and Adam Szeidl (2015). "Imported inputs and productivity." American Economic Review 105(12): 3660-3703.

Haltiwanger, John C. (1997). "Measuring and analyzing aggregate fluctuations: The importance of building from microeconomic evidence." Federal Reserve Bank St. Louis Review 79(3): $55-77$.

Kee, Hiau Looi and Heiwai Tang (2016). "Domestic value added in exports: Theory and firm evidence from China." American Economic Review 106(6): 1402-1436.

Khandelwal, Amit K., Peter K. Schott, and Shang-Jin Wei (2013). "Trade liberalization and embedded institutional reform: Evidence from Chinese exporters." American Economic Review 103(6): 2169-95.

Levinsohn, James (1993). “Testing the imports-as-market-discipline hypothesis." Journal of International Economics, 35(1-2): 1-22.

Lu, Yi and Linhui Yu (2015). "Trade liberalization and markup dispersion: Evidence from China's WTO accession.” American Economic Journal: Applied Economics 7(4): 221-253.

Melitz, Marc J. (2003). "The impact of trade on intra-industry reallocations and aggregate industry productivity." Econometrica 71(6): 1695-1725.

Melitz, Marc J. and Gianmarco I.P. Ottaviano (2008). "Market size, trade, and productivity." Review of Economic Studies 75(1): 295-316.

Murphy, Kevin, Andrei Shleifer and Robert Vishny (1992). "The transition to a market economy: Pitfalls of partial reform.” Quarterly Journal of Economics 107(3): 889-906.

Pavcnik, Nina (2002). "Trade liberalization, exit, and productivity improvement: Evidence from Chilean plants." Review of Economic Studies 69(1): 245-276.

Ravenscraft, David J. and Curtis L. Wagner III (1991). "The role of the FTC's line of business data in testing and expanding the theory of the firm. Journal of Law and Economics 34(2): 703-739.

Raith, Michael (2003). "Competition, risk, and managerial incentives." American Economic Review 93(4): 1425-1436. 
Salvo, Alberto (2010). "Inferring market power under the threat of entry: The case of the Brazilian cement industry.” RAND Journal of Economics 41(2): 326-350.

Schmidt, Klaus M. "Managerial incentives and product market competition." Review of Economic Studies 64(2): 191-213.

Schmitz Jr., James A. (2005). "What determines productivity? Lessons from the dramatic recovery of the U.S. and Canadian iron ore industries following their early 1980s crisis." Journal of Political Economy 113(3): 582-625.

Schor, Adriana (2004). "Heterogeneous productivity response to tariff reduction. Evidence from Brazilian manufacturing firms.” Journal of Development Economics 75(2): 373-396.

Syverson, Chad (2004). "Market structure and productivity: A concrete example." Journal of Political Economy 112(6): 1181-1222.

Topalova, Petia and Amit Khandelwal (2011). "Trade liberalization and firm productivity: The case of India." Review of Economics and Statistics 93(3): 995-1009.

Tybout, James R. and M. Daniel Westbrook (1995). "Trade liberalization and the dimensions of efficiency change in Mexican manufacturing industries." Journal of International Economics, 39(1-2): 53-78.

World Bank. World Integrated Trade Solutions. Online database: http://wits.worldbank.org/ Yu, Miaojie (2014). "Processing trade, tariff reductions and firm productivity: Evidence from Chinese firms.” Economic Journal 125: 943-988. 
Figure 1: Evolution of import tariffs on each sector's output and inputs

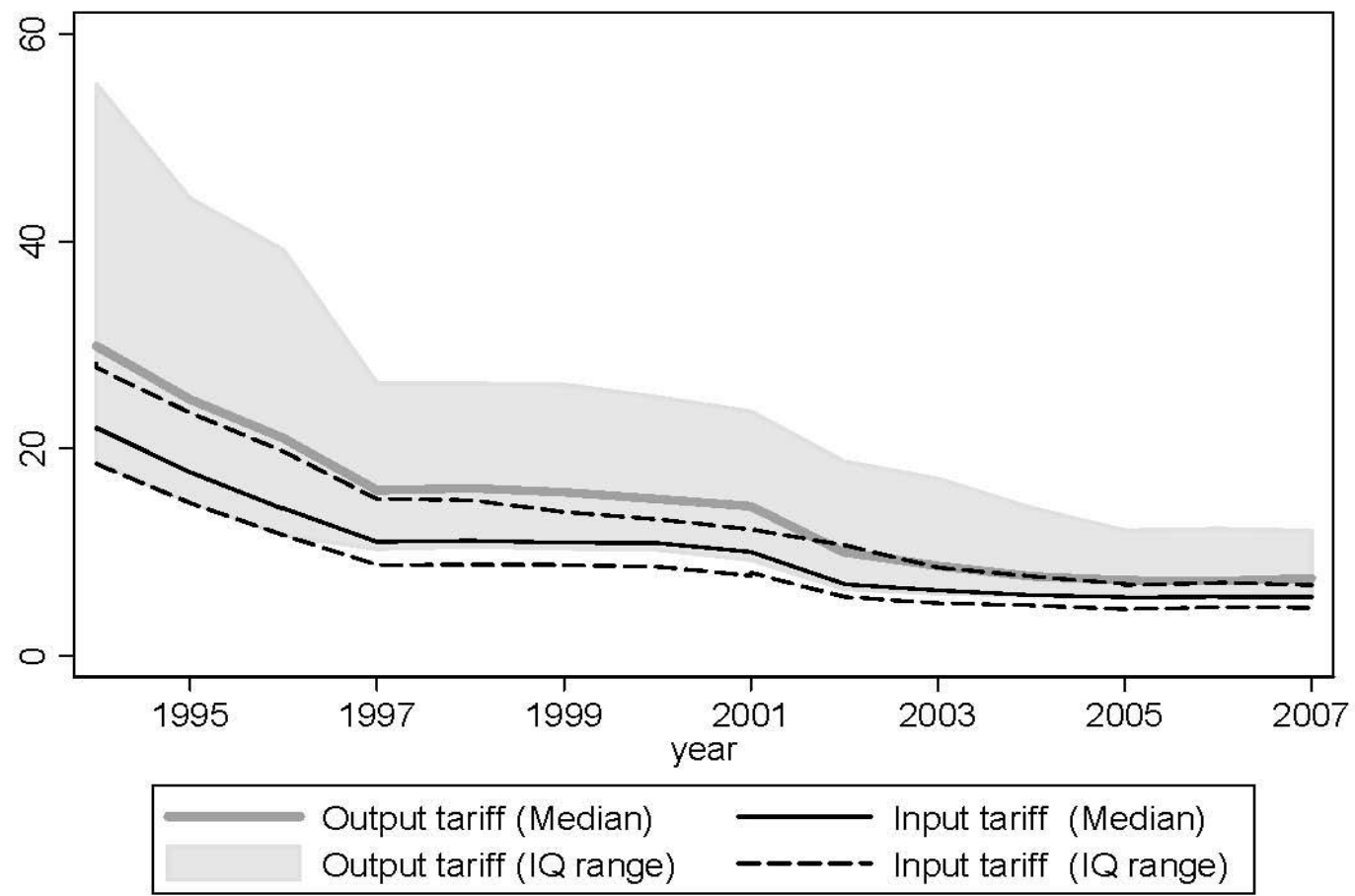

Note: Product-level (output) tariffs at the HS 8-digit level are mapped into 4-digit CIC industries. Multiplying the tariff vector with the 2002 Input-Output table generates input tariffs approximately at the 3digit CIC level. The solid lines show the median tariffs across industries, the shaded area (for output tariffs) and dashed lines (for input tariffs) show the inter-quartile range. 
Figure 2: Fraction of manufacturing sectors subject to high tariffs, non-tariff barriers, or investment restrictions

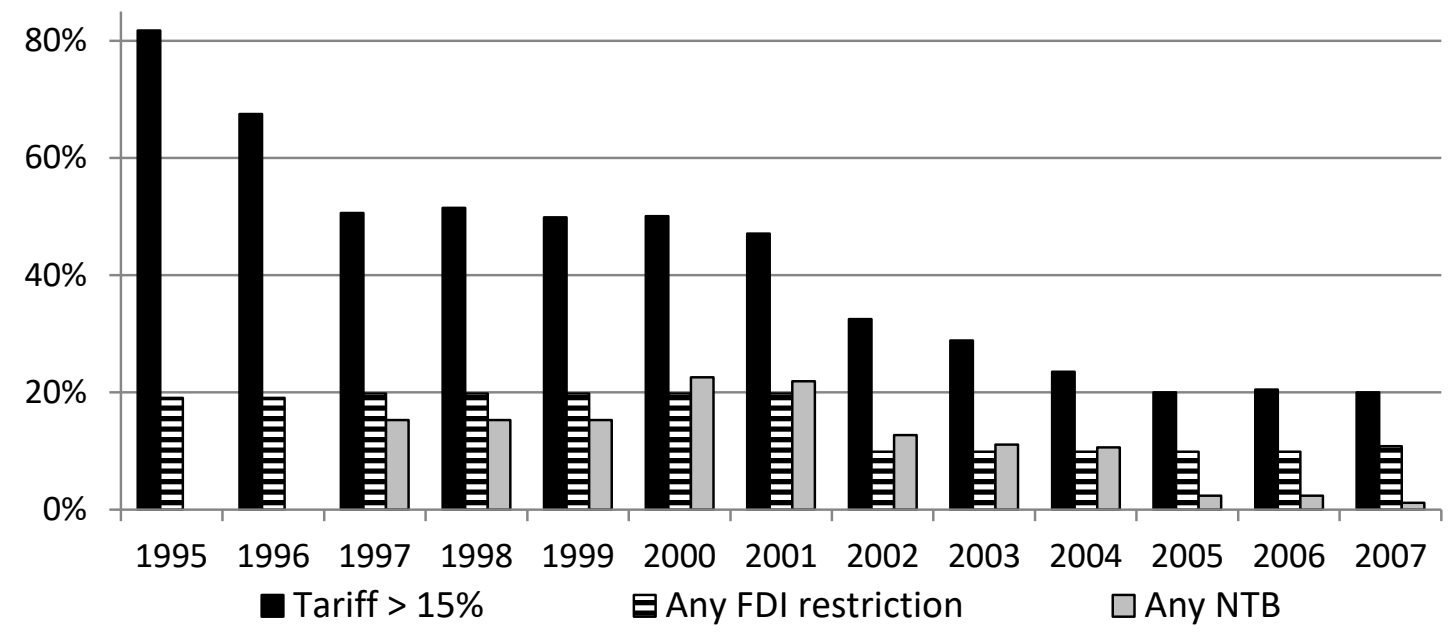

Note: The annual statistics average sectoral dummies across 424 4-digit (CIC) manufacturing sectors. Tarrif rates are from WITS; FDI restrictions and NTB barriers are from annual circulars of the Ministry of Foreign Trade and Economic Cooperation and the Ministry of Commerce. 
Figure 3: Changes in import tariffs by initial tariff level
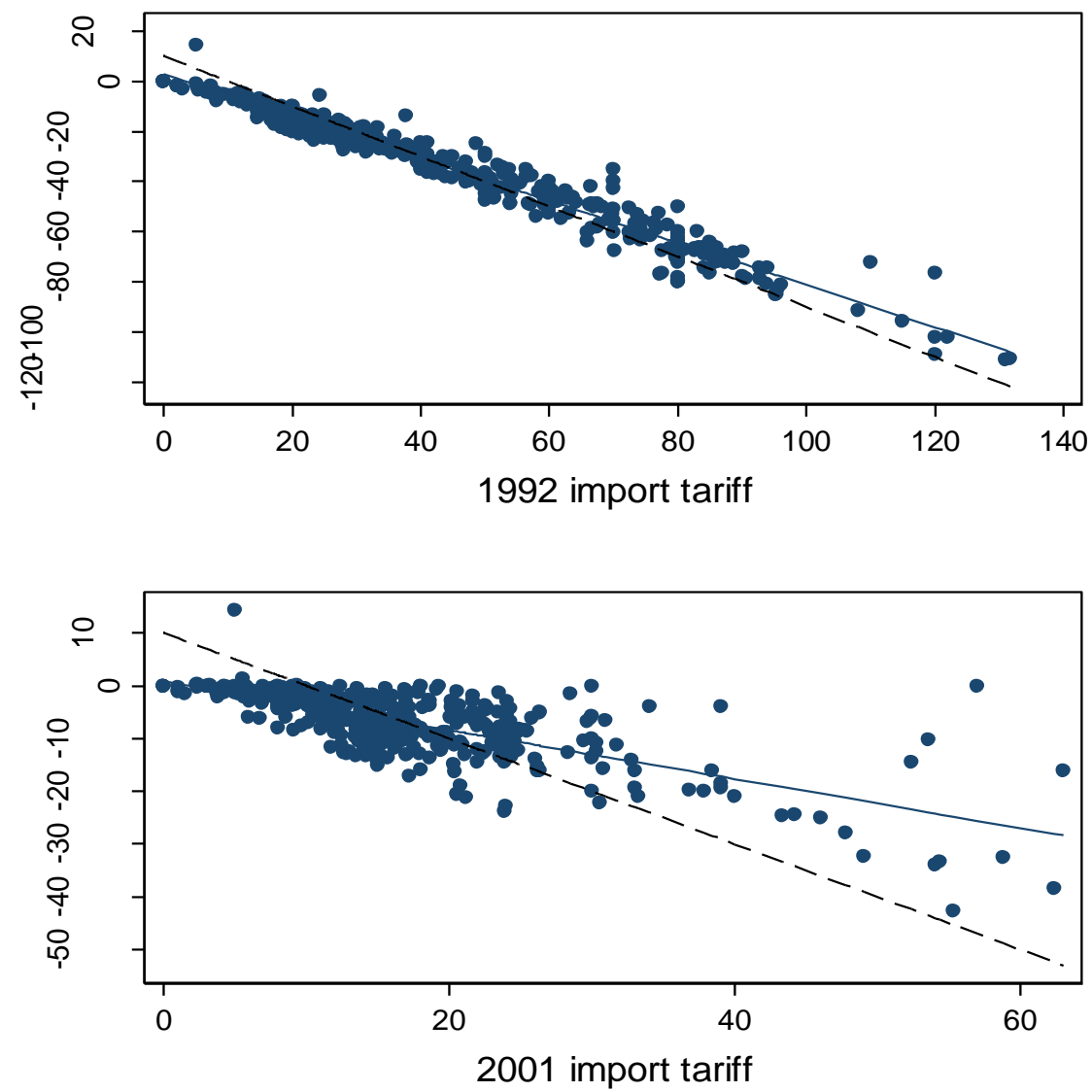

Note: Observations are 4-digit CIC manufacturing sectors. The solid line is the regression line of tariff changes on initial tariffs (with a slope of -0.84 over 1992-2007 and -0.46 over 2001-2007); the dashed line has a slope of -1 (for comparison). 
Table 1: Determinants of changes in tariff protection

\begin{tabular}{|c|c|c|c|c|c|}
\hline \multirow[t]{2}{*}{ Dependent variable: } & \multicolumn{4}{|c|}{$\begin{array}{l}\text { Change in tariffs from } 1998 \text { to } 2007 \\
\qquad\left(\tau_{2007}-\tau_{1998}\right)\end{array}$} & \multirow{2}{*}{$\begin{array}{c}\text { Tariff level } \\
(2002-2007) \\
(5) \\
\end{array}$} \\
\hline & (1) & (2) & (3) & (4) & \\
\hline \multirow[t]{2}{*}{$\mathrm{TFP}_{1998}$} & -0.428 & & -0.852 & -0.467 & \\
\hline & $(0.293)$ & & $(0.448)$ & $(0.499)$ & \\
\hline \multirow[t]{2}{*}{$\mathrm{TFP}_{1998}-\mathrm{TFP}_{1995}$} & & 0.371 & 0.822 & 0.335 & \\
\hline & & $(0.302)$ & $(0.450)$ & $(0.532)$ & \\
\hline \multirow[t]{2}{*}{$\mathrm{TFP}_{1998} *\left(\mathrm{TFP}_{1998}-\mathrm{TFP}_{1995}\right)$} & & & 0.005 & -0.019 & \\
\hline & & & $(0.111)$ & $(0.127)$ & \\
\hline \multirow[t]{2}{*}{$\mathrm{EXP}_{1998}-\mathrm{EXP}_{1995}$} & & & & 0.249 & \\
\hline & & & & $(0.822)$ & \\
\hline \multirow[t]{2}{*}{$\mathrm{EXP}_{2007}-\mathrm{EXP}_{1998}$} & & & & 0.001 & \\
\hline & & & & $(0.026)$ & \\
\hline \multicolumn{6}{|l|}{ Trade categories (BEC) } \\
\hline Intermediates (dummy) & & & & $\begin{array}{c}0.043 \\
(0.032)\end{array}$ & \\
\hline Capital goods (dummy) & & & & $\begin{array}{c}0.017 \\
(0.033)\end{array}$ & \\
\hline Consumer goods (dummy) & & & & $\begin{array}{c}0.007 \\
(0.031)\end{array}$ & \\
\hline \multicolumn{6}{|l|}{ U.S. industry characteristics } \\
\hline Differentiated goods (Rauch dummy) & & & & $\begin{array}{l}-0.008 \\
(0.012)\end{array}$ & \\
\hline Sales expenditure intensity & & & & $\begin{array}{c}0.053 \\
(0.021)\end{array}$ & \\
\hline R\&D intensity & & & & $\begin{array}{l}-0.497 \\
(0.395)\end{array}$ & \\
\hline Advertising intensity & & & & $\begin{array}{l}-0.315 \\
(0.193)\end{array}$ & \\
\hline \multicolumn{6}{|l|}{ Chinese industry characteristics } \\
\hline Top 4 market share & & & & $\begin{array}{l}-0.016 \\
(0.023)\end{array}$ & \\
\hline Log employment & & & & $\begin{array}{l}-0.837 \\
(0.343)\end{array}$ & $\begin{array}{l}-0.003 \\
(0.001)\end{array}$ \\
\hline $\log (\mathrm{K} / \mathrm{Y})$ ratio & & & & $\begin{array}{c}0.925 \\
(0.963)\end{array}$ & \\
\hline SOE share in sectoral sales & & & & $\begin{array}{l}-0.011 \\
(0.019)\end{array}$ & $\begin{array}{c}0.004 \\
(0.002)\end{array}$ \\
\hline Elementary education share & & & & $\begin{array}{c}0.133 \\
(0.099)\end{array}$ & \\
\hline Maximum tariff level & & & & & $\begin{array}{c}0.524 \\
(0.018)\end{array}$ \\
\hline Sector (2-digit) FE & yes & & yes & yes & \\
\hline Industry (4-digit) FE & & & & & yes \\
\hline R-squared & 0.35 & 0.01 & 0.41 & 0.49 & 0.98 \\
\hline Observations & 410 & 410 & 410 & 370 & 2,484 \\
\hline
\end{tabular}

Note: Estimates in column (4) additionally contain year FE and the same additional controls as used in firm-level regressions below (sectoral output, export, and the foreign firm share). Standard errors in parentheses. 
Table 2 Effect of tariffs on imports and domestic prices

(a) Imports (2000-2007)

\begin{tabular}{|c|c|c|c|c|c|}
\hline & \multicolumn{5}{|c|}{$\begin{array}{l}\text { Dependent variable is ordinary trade imports into China (in logs) } \\
\text { at the product level (6-digit HS) }\end{array}$} \\
\hline & All goods & Materials & $\begin{array}{l}\text { Intermediate } \\
\text { inputs }\end{array}$ & Capital goods & Consumer goods \\
\hline & (1a) & $(2 a)$ & $(3 a)$ & $(4 a)$ & $(5 a)$ \\
\hline \multirow[t]{2}{*}{ Import tariff (lagged) } & -3.112 & -1.559 & -4.349 & -2.325 & -1.980 \\
\hline & $(0.331)$ & $(0.826)$ & $(0.668)$ & $(0.692)$ & $(0.631)$ \\
\hline Observations & 127,049 & 8,458 & 73,351 & 19,013 & 26,061 \\
\hline Year FE & yes & yes & yes & yes & yes \\
\hline Product FE & yes & yes & yes & yes & yes \\
\hline
\end{tabular}

Note: All coefficients are estimated using separate regressions based on information of firm-level trade transactions from China Custom's that are aggregated to the product level. Duty-free imports are excluded. The regressions allow for a different elasticity for imports entering through trade intermediaries (not reported). The instrument, from 2001 onwards, is the maximum allowable tariff under the WTO agreement. Standard errors in parentheses are clustered at the product level.

(b) Domestic price level (1998-2007)

Dependent variable is an index of the Chinese domestic price level at the industry level (4-digit CIC)

\begin{tabular}{|c|c|c|c|c|c|}
\hline & $\begin{array}{l}\text { All goods } \\
\text { (1b) }\end{array}$ & $\begin{array}{l}\text { Materials } \\
\text { (2b) }\end{array}$ & $\begin{array}{c}\text { Intermediate } \\
\text { inputs } \\
(3 b)\end{array}$ & Capital goods & Consumer goods \\
\hline \multicolumn{6}{|c|}{ (i) Preferred series: 4-digit where available and 2-digit elsewhere } \\
\hline Import tariff (lagged) & $\begin{array}{c}0.296 \\
(0.090)\end{array}$ & $\begin{array}{c}0.320 \\
(0.212)\end{array}$ & $\begin{array}{c}0.492 \\
(0.191)\end{array}$ & $\begin{array}{c}0.174 \\
(0.088)\end{array}$ & $\begin{array}{c}0.011 \\
(0.106)\end{array}$ \\
\hline \multicolumn{6}{|c|}{ (ii) Alternative series (1): constructed from the firm-level information } \\
\hline Import tariff (lagged) & $\begin{array}{c}0.283 \\
(0.100)\end{array}$ & $\begin{array}{l}-0.309 \\
(0.212)\end{array}$ & $\begin{array}{c}0.493 \\
(0.204)\end{array}$ & $\begin{array}{c}0.197 \\
(0.091)\end{array}$ & $\begin{array}{c}0.049 \\
(0.112)\end{array}$ \\
\hline \multicolumn{6}{|c|}{ (iii) Alternative series (2): aggregate deflators constructed by NBS for 2-digit sectors } \\
\hline Import tariff (lagged) & $\begin{array}{c}0.255 \\
(0.092)\end{array}$ & $\begin{array}{c}0.298 \\
(0.244)\end{array}$ & $\begin{array}{c}0.442 \\
(0.169)\end{array}$ & $\begin{array}{c}0.182 \\
(0.158)\end{array}$ & $\begin{array}{l}-0.085 \\
(0.089)\end{array}$ \\
\hline Observations & 4,240 & 70 & 1,950 & 1,180 & 980 \\
\hline Year FE & yes & yes & yes & yes & yes \\
\hline Industry or sector FE & yes & yes & yes & yes & yes \\
\hline
\end{tabular}

Note: All coefficients are estimated using separate regressions for 4-digit industries. The instrument, from 2001 onwards, is the maximum allowable tariff under the WTO agreement. In panel (i), the price index from 1998 to 2003 is calculated by aggregating firm-level price changes to the 4-digit industry level as described in Section 4; the index is extended to the end of the sample period using a sectoral (2-digit) price index taken from China's Statistical Yearbook. In panel (ii), the detailed price index for 1998-2003 is calculated omitting fewer outlier observations. In Panel (iii), the 2-digit sector-level price index is used throughout. Standard errors in parentheses are clustered at the industry level. 
Table 3: Effect of tariffs on firm-level markups and productivity

\begin{tabular}{|c|c|c|c|c|c|c|}
\hline & \multicolumn{6}{|c|}{ Dependent variable is the firm-level markup (in logs) } \\
\hline & \multicolumn{2}{|c|}{ No weights } & \multicolumn{2}{|c|}{$\begin{array}{l}\text { Within-industry output } \\
\text { share weights }\end{array}$} & \multicolumn{2}{|c|}{ Output weights } \\
\hline & (1a) & $(2 a)$ & (3a) & $(4 a)$ & $(5 a)$ & $(6 a)$ \\
\hline Output tariff (lagged) & $\begin{array}{c}0.045 \\
(0.041)\end{array}$ & $\begin{array}{c}0.058 \\
(0.044)\end{array}$ & $\begin{array}{c}0.07 \\
(0.043)\end{array}$ & $\begin{array}{c}0.095 \\
(0.051)\end{array}$ & $\begin{array}{c}0.375 \\
(0.110)\end{array}$ & $\begin{array}{c}0.543 \\
(0.120)\end{array}$ \\
\hline Input tariff (lagged) & $\begin{array}{l}-0.227 \\
(0.106)\end{array}$ & $\begin{array}{l}-0.969 \\
(0.074)\end{array}$ & $\begin{array}{c}0.016 \\
(0.169)\end{array}$ & $\begin{array}{l}-0.733 \\
(0.094)\end{array}$ & $\begin{array}{l}-0.651 \\
(0.354)\end{array}$ & $\begin{array}{l}-1.173 \\
(0.181)\end{array}$ \\
\hline Firm FE & yes & yes & yes & yes & yes & yes \\
\hline Year FE & yes & & yes & & yes & \\
\hline $\begin{array}{l}\text { Sector-year FE } \\
\text { Observations }\end{array}$ & $1,293,495$ & $\begin{array}{c}\text { yes } \\
1,295,372\end{array}$ & $1,211,861$ & $\begin{array}{c}\text { yes } \\
1,213,586\end{array}$ & $1,293,495$ & $\begin{array}{c}\text { yes } \\
1,295,372\end{array}$ \\
\hline
\end{tabular}

(b) Productivity (1998-2007)

\begin{tabular}{|c|c|c|c|c|c|c|}
\hline & \multicolumn{6}{|c|}{ Dependent variable is firm-level productivity (TFP, in logs) } \\
\hline & \multicolumn{2}{|c|}{ No weights } & \multicolumn{2}{|c|}{$\begin{array}{l}\text { Within-industry output } \\
\text { share weights }\end{array}$} & \multicolumn{2}{|c|}{ Output weights } \\
\hline & (1b) & $(2 b)$ & $(3 b)$ & (4b) & $(5 b)$ & (6b) \\
\hline \multirow[t]{2}{*}{ Output tariff (lagged) } & -0.369 & -0.316 & -0.176 & -0.107 & -0.263 & -0.387 \\
\hline & $(0.139)$ & $(0.097)$ & $(0.088)$ & $(0.062)$ & $(0.155)$ & $(0.115)$ \\
\hline \multirow[t]{2}{*}{ Input tariff (lagged) } & -0.806 & -1.031 & 1.790 & -1.621 & -2.395 & -0.682 \\
\hline & $(0.385)$ & $(0.167)$ & $(0.323)$ & $(0.144)$ & $(0.616)$ & $(0.249)$ \\
\hline Firm FE & yes & yes & yes & yes & yes & yes \\
\hline Year FE & yes & & yes & & yes & \\
\hline Sector-year FE & & yes & & yes & & yes \\
\hline Observations & $1,275,041$ & $1,276,922$ & $1,194,720$ & $1,196,451$ & $1,275,041$ & $1,276,922$ \\
\hline
\end{tabular}

Note: Instrument from 2001 onwards is the maximum allowable tariff under the WTO agreement. The sample only includes firms that did not switch industry. Standard errors in parentheses are clustered two-ways at the industry-year and the firm level. 
Table 4: Decomposing the effect of tariffs on industry performance

(a) Price-cost markups (1998-2007)

\begin{tabular}{|c|c|c|c|c|c|}
\hline & $\begin{array}{c}\text { Total effect } \\
\text { (1a) }\end{array}$ & $\begin{array}{c}\text { Within } \\
(2 \mathrm{a})\end{array}$ & $\begin{array}{c}\text { Between } \\
(3 a)\end{array}$ & $\begin{array}{c}\text { Entry } \\
(4 a)\end{array}$ & $\begin{array}{l}\text {-Exit } \\
(5 a)\end{array}$ \\
\hline \multirow[t]{2}{*}{ Change in Output tariff } & 0.152 & 0.122 & 0.010 & 0.014 & 0.005 \\
\hline & $(0.066)$ & $(0.043)$ & $(0.013)$ & $(0.039)$ & $(0.009)$ \\
\hline \multirow[t]{2}{*}{ Change in Input tariff } & -0.292 & -0.045 & 0.040 & -0.282 & -0.005 \\
\hline & $(0.149)$ & $(0.098)$ & $(0.030)$ & $(0.088)$ & $(0.021)$ \\
\hline Industry FE & yes & yes & yes & yes & yes \\
\hline \multirow[t]{2}{*}{ Observations } & 844 & 844 & 844 & 844 & 844 \\
\hline & (1b) & $(2 b)$ & $(3 b)$ & $(4 b)$ & $(5 b)$ \\
\hline \multirow[t]{2}{*}{ Change in Output tariff } & 0.221 & 0.150 & -0.023 & 0.095 & 0.001 \\
\hline & $(0.049)$ & $(0.032)$ & $(0.009)$ & $(0.026)$ & $(0.006)$ \\
\hline \multirow[t]{2}{*}{ Change in Input tariff } & -0.400 & -0.146 & 0.068 & -0.319 & -0.002 \\
\hline & $(0.127)$ & $(0.083)$ & $(0.024)$ & $(0.068)$ & $(0.015)$ \\
\hline Industry-year weights & yes & yes & yes & yes & yes \\
\hline Observations & 844 & 844 & 844 & 844 & 844 \\
\hline
\end{tabular}

(b) Productivity (1998-2007)

\begin{tabular}{lccccc}
\hline \hline & Total effect & Within & Between & Entry & -Exit \\
& $(1 \mathrm{c})$ & $(2 \mathrm{c})$ & $(3 \mathrm{c})$ & $(4 \mathrm{c})$ & $(5 \mathrm{c})$ \\
\hline Change in Output tariff & -0.569 & -0.200 & 0.042 & -0.428 & -0.017 \\
& $(0.137)$ & $(0.074)$ & $(0.028)$ & $(0.106)$ & $(0.016)$ \\
Change in Input tariff & -1.160 & -0.297 & 0.246 & -1.080 & -0.030 \\
& $(0.312)$ & $(0.168)$ & $(0.065)$ & $(0.241)$ & $(0.036)$ \\
Industry FE & yes & yes & yes & yes & yes \\
Observations & 844 & 844 & 844 & 844 & 844 \\
\hline & $(1 \mathrm{~d})$ & $(2 \mathrm{~d})$ & $(3 \mathrm{~d})$ & $(4 \mathrm{~d})$ & $(5 \mathrm{~d})$ \\
\hline Change in Output tariff & -0.465 & -0.209 & 0.049 & -0.302 & -0.003 \\
& $(0.141)$ & $(0.071)$ & $(0.022)$ & $(0.097)$ & $(0.010)$ \\
Change in Input tariff & -1.236 & -0.551 & 0.170 & -0.837 & -0.019 \\
Industry-year weights & $(0.363)$ & $(0.184)$ & $(0.056)$ & $(0.252)$ & $(0.026)$ \\
Observations & yes & yes & yes & yes & yes \\
\hline \hline
\end{tabular}

Note: Separate regressions in each column. The instrument from 2001 onwards is the change in the maximum allowable tariff under the WTO agreement. Dependent variables are the terms of a linear decomposition of industrylevel change in markup or productivity. The sample pools annualized growth rates over 2 sub-periods (1998-2001 and 2001-2007) that cover 424 and 420 industries, respectively. Standard errors in parentheses. 
Table 5: Use of imported intermediates

(a) Fraction of firms using imported intermediates

\begin{tabular}{cccc}
\hline \hline & All imports & Processing trade & Ordinary trade \\
& $(1 \mathrm{a})$ & $(2 \mathrm{a})$ & $(3 \mathrm{a})$ \\
\hline 2000 & $9.6 \%$ & $6.9 \%$ & $6.6 \%$ \\
2007 & $10.9 \%$ & $8.7 \%$ & $7.1 \%$ \\
\hline
\end{tabular}

(b) Share of imported intermediates in total input use for the sample of matched firms

\begin{tabular}{cccc}
\hline \hline & All imports & Processing trade & Ordinary trade \\
& $(1 \mathrm{~b})$ & $(2 \mathrm{~b})$ & $(3 \mathrm{~b})$ \\
\hline 2000 & $29.1 \%$ & $19.7 \%$ & $9.3 \%$ \\
2007 & $27.3 \%$ & $17.5 \%$ & $9.8 \%$ \\
\hline
\end{tabular}

(c) Share of imported intermediates in total input use for the entire manufacturing sector

\begin{tabular}{lccc}
\hline \hline & All imports & Processing trade & Ordinary trade \\
& $(1 \mathrm{c})$ & $(2 \mathrm{c})$ & $(3 \mathrm{c})$ \\
\hline 2000 & $13.4 \%$ & $6.2 \%$ & $7.2 \%$ \\
2007 & $13.5 \%$ & $5.9 \%$ & $7.5 \%$ \\
\hline \hline
\end{tabular}

Note: Calculations in panels (a) and (b) are based on a sample of firms merged between the NBS firmlevel data and the Custom's trade-transactions data; in panel (c), the denominator is calculated using all firms from the Custom's data and the numerator uses a weighted average of the aggregate input use over all firms in the NBS data or using the estimate for manufacturing from the National Accounts. 
Table 6: Effect of tariffs on growth, exit, and management replacement

\begin{tabular}{|c|c|c|c|c|}
\hline Dependent variable: & $\begin{array}{c}\text { Output growth } \\
\text { (year on year) } \\
(1)\end{array}$ & $\begin{array}{c}\text { Dummy for firm } \\
\text { survival } \\
\text { (2) } \\
\end{array}$ & $\begin{array}{c}\text { Dummy for CEO } \\
\text { replacement } \\
\text { (3) } \\
\end{array}$ & $\begin{array}{l}\text { Dummy for CEO } \\
\text { replacement } \\
(4) \\
\end{array}$ \\
\hline SOE dummy & $\begin{array}{l}-0.1187 \\
(0.0059)\end{array}$ & $\begin{array}{l}-0.0776 \\
(0.0035)\end{array}$ & $\begin{array}{c}0.0537 \\
(0.0013)\end{array}$ & $\begin{array}{c}0.0606 \\
(0.0025)\end{array}$ \\
\hline Output tariff (lagged) & $\begin{array}{c}-0.0110 \\
(0.0004)\end{array}$ & $\begin{array}{c}0.0005 \\
(0.0002)\end{array}$ & & $\begin{array}{c}0.0004 \\
(0.0002)\end{array}$ \\
\hline Output tariff (lagged) $*$ SOE & $\begin{array}{c}-0.0013 \\
(0.0004)\end{array}$ & $\begin{array}{l}-0.0004 \\
(0.0002)\end{array}$ & & $\begin{array}{c}-0.0004 \\
(0.0002)\end{array}$ \\
\hline Output growth & & & $\begin{array}{l}-0.0099 \\
(0.0008)\end{array}$ & $\begin{array}{c}-0.0055 \\
(0.0014)\end{array}$ \\
\hline Output growth $*$ SOE & & & $\begin{array}{l}-0.0057 \\
(0.0016)\end{array}$ & $\begin{array}{l}-0.0075 \\
(0.0029)\end{array}$ \\
\hline Output growth $*$ output tariff (lagged) & & & & $\begin{array}{c}-0.0002 \\
(0.0001)\end{array}$ \\
\hline Output growth $*$ output tariff $(\mathrm{lag}) * \mathrm{~S}$ & & & & $\begin{array}{c}0.0004 \\
(0.0002)\end{array}$ \\
\hline Firm FE, Year FE, control variables & yes & yes & yes & yes \\
\hline Observations & $1,318,033$ & $1,341,456$ & 924,693 & 841,921 \\
\hline
\end{tabular}

Note: All regressions use data for 1998-2007 and control for capital-intensity and CEO tenure. Standard errors in parentheses are clustered two-ways, at the industry-year and at the firm level. 
Table 7: Effect of tariffs on the level of markup and productivity by firm status

\begin{tabular}{lcc}
\hline \hline Dependent variable: & $\begin{array}{c}\text { Markup } \\
(1)\end{array}$ & $\begin{array}{c}\text { Productivity } \\
(2)\end{array}$ \\
\hline Output tariff (lagged) & & \\
$*$ Incumbent & 0.004 & -0.454 \\
& $(0.040)$ & $(0.143)$ \\
$*$ Entrant & 0.017 & -0.568 \\
& $(0.054)$ & $(0.202)$ \\
$*$ Exiting firm & -0.010 & -0.373 \\
& $(0.044)$ & $(0.148)$ \\
Input tariff (lagged) & & \\
$*$ Incumbent & -0.185 & -0.284 \\
& $(0.107)$ & $(0.386)$ \\
$*$ Entrant & -0.153 & -0.914 \\
& $(0.164)$ & $(0.507)$ \\
$*$ Exiting & -0.083 & -0.363 \\
& $(0.141)$ & $(0.403)$ \\
Industry FE & yes & yes \\
Year by firm-status interaction FE & yes & yes \\
Observations & 901,048 & 904,960 \\
\hline \hline Note: Sample covers the period 1999-2006 and only includes firms that do not switch industry and \\
survive for at least two years. For entrants and exiting firms we exclude, respectively, their first and last \\
year of operation to avoid calculating productivity using output for less than a full year. Instrument from \\
2001 onwards is the maximum allowable tariff under the WTO agreement. Standard errors in parentheses \\
are clustered two-ways at the industry-year and at the firm level. \\
\end{tabular}

